June $1999 \cdot$ NREL/TP-550-25285

\title{
Colorado Homeowner Preferences on Energy and Environmental Policy
}

Barbara C. Farhar, Ph.D.
Timothy C. Coburn, Ph.D.

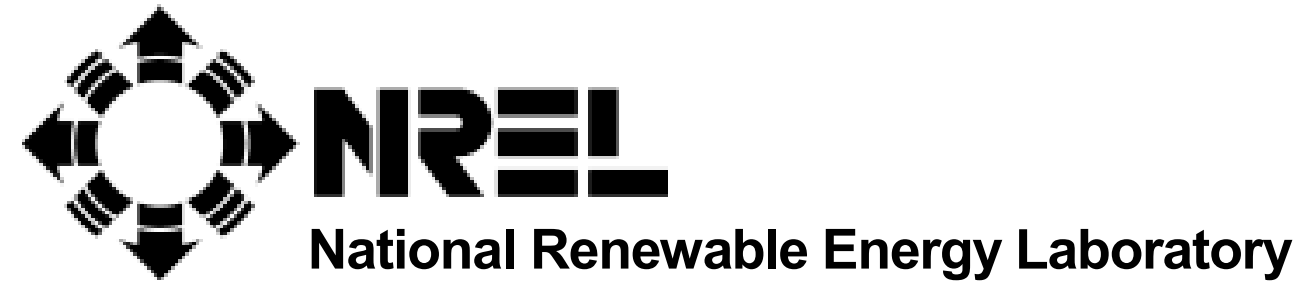

1617 Cole Boulevard

Golden, Colorado 80401-3393

NREL is a U.S. Department of Energy Laboratory

Operated by Midwest Research Institute $\bullet$ Battelle $\bullet$ Bechtel

Contract No. DE-AC36-98-G010337 
June $1999 \cdot$ NREL/TP-550-25285

\section{Colorado Homeowner Preferences on Energy and Environmental Policy}

Barbara C. Farhar, Ph.D.

Timothy C.Coburn, Ph.D.

Prepared under Task No. PV908201

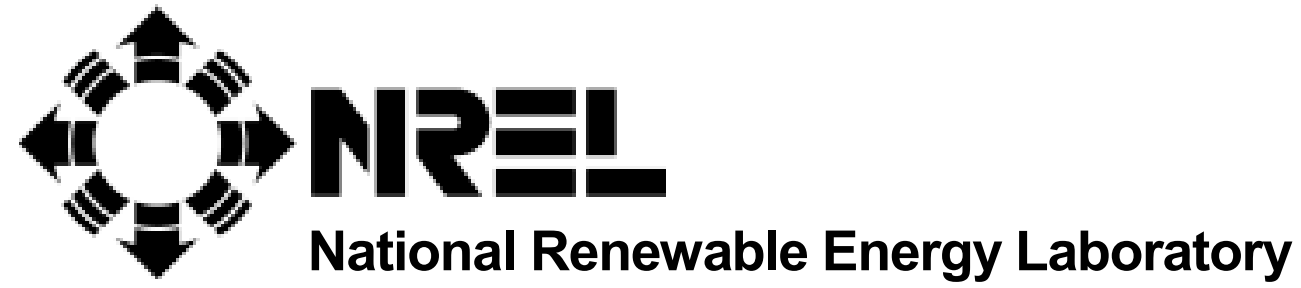

1617 Cole Boulevard

Golden, Colorado 80401-3393

NREL is a U.S. Department of Energy Laboratory

Operated by Midwest Research Institute $\bullet$ Battelle $\bullet$ Bechtel

Contract No. DE-AC36-98-G010337 


\section{NOTICE}

This report was prepared as an account of work sponsored by an agency of the United States government. Neither the United States government nor any agency thereof, nor any of their employees, makes any warranty, express or implied, or assumes any legal liability or responsibility for the accuracy, completeness, or usefulness of any information, apparatus, product, or process disclosed, or represents that its use would not infringe privately owned rights. Reference herein to any specific commercial product, process, or service by trade name, trademark, manufacturer, or otherwise does not necessarily constitute or imply its endorsement, recommendation, or favoring by the United States government or any agency thereof. The views and opinions of authors expressed herein do not necessarily state or reflect those of the United States government or any agency thereof.

Available to DOE and DOE contractors from:

Office of Scientific and Technical Information (OSTI)

P.O. Box 62

Oak Ridge, TN 37831

Prices available by calling 423-576-8401

Available to the public from:

National Technical Information Service (NTIS)

U.S. Department of Commerce

5285 Port Royal Road

Springfield, VA 22161

$703-605-6000$ or $800-553-6847$

or

DOE Information Bridge

http://www.doe.gov/bridge/home.html

Printed on paper containing at least $50 \%$ wastepaper, including $20 \%$ postconsumer waste 


\section{Contents}

$\underline{\text { Page }}$

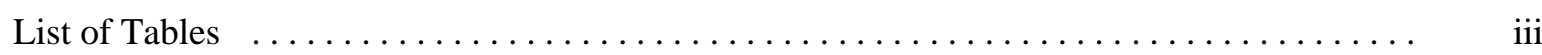

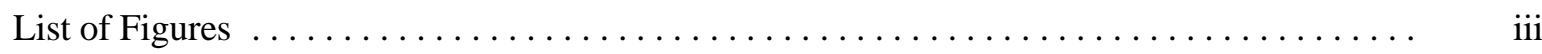

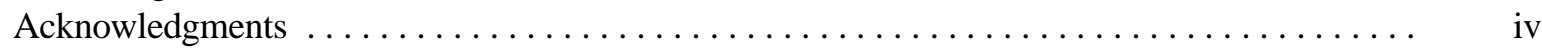

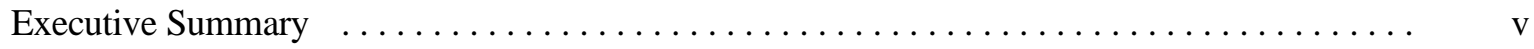

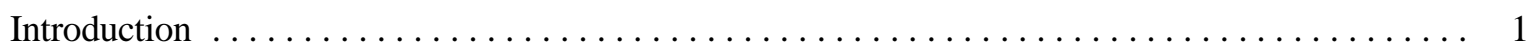

Section One: Energy and the Environment $\ldots \ldots \ldots \ldots \ldots \ldots \ldots \ldots \ldots \ldots \ldots \ldots \ldots \ldots \ldots \ldots \ldots \ldots$

Section Two: Comparative Energy Preferences $\ldots \ldots \ldots \ldots \ldots \ldots \ldots \ldots \ldots \ldots \ldots \ldots$

Perceived Environmental Threat of Various Energy Sources $\ldots \ldots \ldots \ldots \ldots \ldots \ldots$

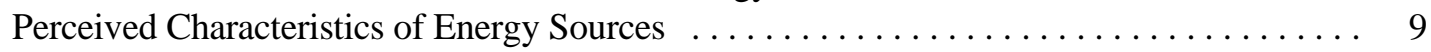

Preferences among Renewable Energy Alternatives $\ldots \ldots \ldots \ldots \ldots \ldots \ldots \ldots \ldots$

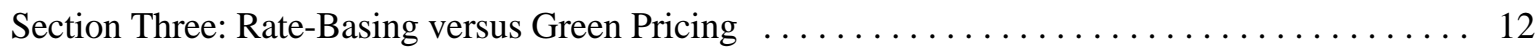

Willingness to Pay a Slightly Higher Electricity Rate (Rate-Basing) $\ldots \ldots \ldots \ldots \ldots \ldots 13$

Stated Likelihood of Voluntarily Paying More for Green Power (Green-Pricing) . . . . . . 14

Willingness to Voluntarily Pay More for Green Power (Green-Pricing) $\ldots \ldots \ldots \ldots \ldots \ldots$

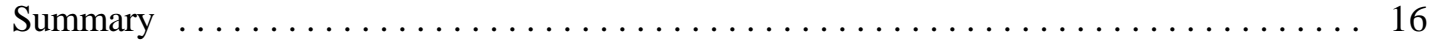

Section Four: Utility Restructuring $\quad \ldots \ldots \ldots \ldots \ldots \ldots \ldots \ldots \ldots \ldots \ldots \ldots \ldots \ldots \ldots \ldots \ldots \ldots \ldots \ldots$

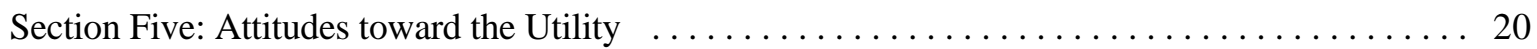

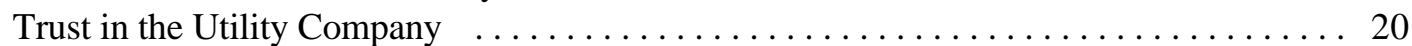

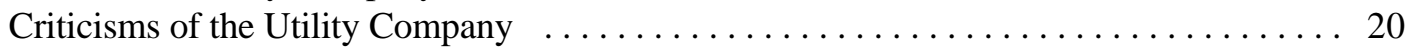

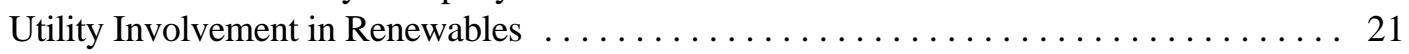

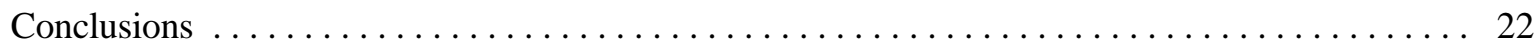

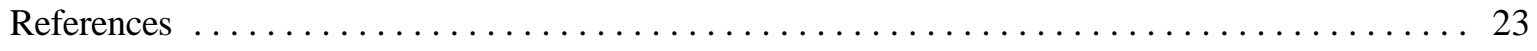

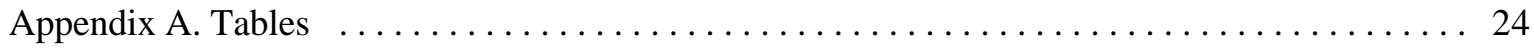

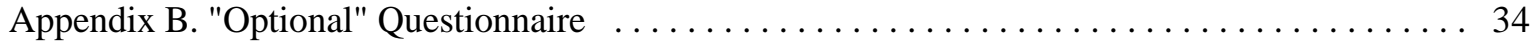




\section{List of Tables}

1. Perceived Importance of Environmental Problems $\ldots \ldots \ldots \ldots \ldots \ldots \ldots \ldots \ldots \ldots$

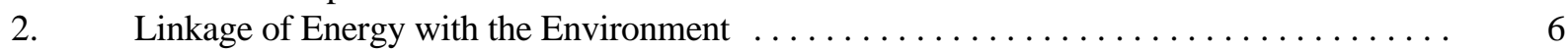

3. Perceived Environmental Threat of Various Sources of Electricity $\ldots \ldots \ldots \ldots \ldots \ldots \ldots$

4. Top-Ranked Renewable Energy Sources for Colorado $\ldots \ldots \ldots \ldots \ldots \ldots \ldots \ldots \ldots \ldots$

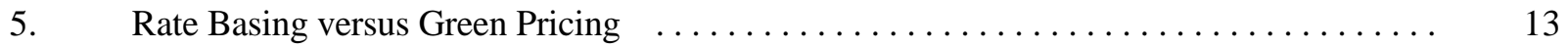

6. Likelihood of Paying More for Green Power in a Green-Pricing Program $\ldots \ldots \ldots \ldots$.

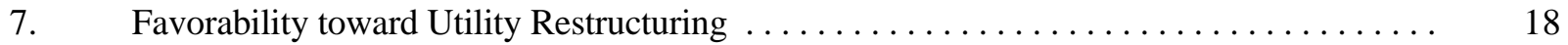

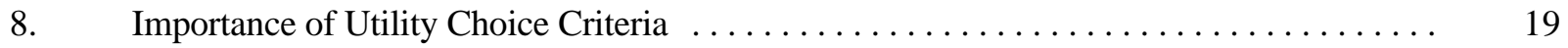

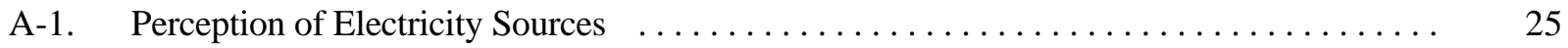

A-2. Incremental Monthly Amount Respondents Are Willing to Pay in

Electricity Rate Increases to Develop Renewable Forms of Energy $\ldots \ldots \ldots \ldots \ldots \ldots .26$

A-3. Incremental Monthly Amount Respondents Are Willing to Voluntarily Pay in a

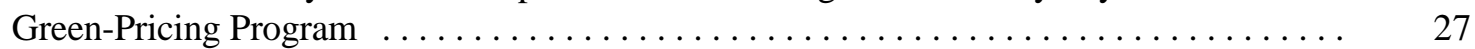

A-4. Reasons for Attitude toward Utility Restructuring (Open-ended question) $\ldots \ldots \ldots \ldots .28$

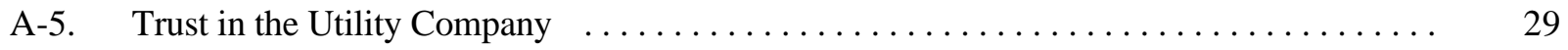

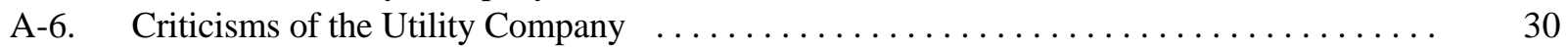

A-7. Position toward Electric Utilities Adding Renewables to Their Fuel Mix $\ldots \ldots \ldots \ldots \ldots . \quad 31$

A-8. Attitudes toward Utility Involvement in Renewables $\ldots \ldots \ldots \ldots \ldots \ldots \ldots \ldots \ldots \ldots$

\section{List of Figures}

1. Perceived Environmental Threat of Various Sources of Electricity $\ldots \ldots \ldots \ldots \ldots \ldots$

2. Incremental Monthly Amount Respondents Are Willing to Pay Under a

Rate-Basing Program to Develop Renewable Forms of Energy (Cumulative) $\ldots \ldots \ldots . \quad 14$

3. Incremental Monthly Amount Respondents Are Willing to

Pay Voluntarily under a Green-Pricing Program (Cumulative) $\ldots \ldots \ldots \ldots \ldots \ldots \ldots$ 


\section{Acknowledgments}

The Colorado Governor's Office of Energy Conservation (OEC), along with the National Renewable Energy Laboratory's STEP-2 Program, partnered to fund this research. The OEC funded the research at the University of Colorado, Boulder. Program managers were Marc Roper of the Colorado Office of Energy Conservation and Carol Tombari of NREL's State and Local Programs Office. Professor Dennis Mileti, Chair, and Steve Graham, Staff Assistant, Department of Sociology, University of Colorado, Boulder, provided encouragement and essential administrative support to the project. Ron Judkoff and Sheila Hayter of NREL's Center for Buildings and Thermal Systems extended themselves to make sure the project would be completed. Many colleagues in the energy and utility communities encouraged the completion of this work.

The authors would like to acknowledge other key contributors to the quantitative phase of this study, of which the research reported here is a part:

Jan Buhrman, Ph.D., U.S. Environmental Protection Agency, Denver

Elizabeth Sheff, Graduate student, Department of Sociology, University of Colorado, Boulder

K. L. Berry, Matrix International, Consultant, data analysis

Jeff Haugen, Left Brain Concepts, Consultant, data analysis

Direct Marketing Designs, Inc., and The Polk Company, sampling frame, sampling, and mailing services Alexander's Data Services, Inc., data entry and cleaning

David Lillie, User Interface Services, data base integrity

Rochelle Watters, NREL, project coordination and support, manuscript preparation

Erica Henningsen, NREL, manuscript preparation

University of Colorado Printing Services, printing services

University of Colorado Mail Room, mail handling.

The authors also want to acknowledge the 206 Colorado homeowners who completed the questionnaire.

Thanks also to Marc Roper, Christi Herig, Sheila Hayter, Karl Rábago, and Nancy Collins for helpful comments on the manuscript. David Crawford, Susan Sczepanski, Kay Vernon, Demetri Paiz, and Charles Botkin prepared the manuscript. 


\section{Colorado Homeowner Preferences on Energy and Environmental Policy}

\section{Executive Summary}

Colorado homeowners follow national trends in preferring renewable energy over conventional energy sources. They tend to view nuclear energy, coal, and oil as posing environmental threats when used to produce electricity. Homeowners regard solar and wind power as the best electricity sources from an environmental standpoint.

Solar energy and wind power are also ranked highest of all electricity sources on a number of other factors, including safety, cost, abundance, national selfreliance, meeting growing energy demands, stimulating economic development, diversifying our energy mix, adding high-tech jobs, and improving our economy.

The most important environmental problems defined by the survey respondents are water pollution, air pollution, and resource depletion. Respondents indicate that they perceive only a moderate link between energy and environmental problems. This may be because the connection between energy and water pollution is not clear to homeowners.

When asked to rank 11 renewable energy sources that would best meet the energy needs of Colorado, homeowners most frequently select PV, wind power, and passive solar energy.

Most homeowners favor the idea of utilities adding renewables to their resource mix. Among those "favorable, environmental benefits" and "conserving natural resources" are important reasons.

\section{Report Highlights}

- Water and air pollution are perceived as the most important environmental problems

- Environmental problems are viewed as somewhat energy-related

- Solar and wind power are viewed as the least environmentally threatening sources of electricity; nuclear energy and coal are viewed as the most environmentally threatening

- Among renewables, PV and wind power are seen as the best sources for meeting energy needs

- Homeowners trust their utility companies, and want them to add renewables to their energy mix

- Homeowners prefer to see the costs of developing renewables shared broadly, either through federal subsidies of electricity generation from renewables or modest increases in electric rates

- Most homeowners are willing to pay a higher electricity rate for green power, but one in five homeowners are unwilling to pay a rate increase for green power

- When it comes to voluntary green pricing programs, most homeowners are willing to pay an additional amount more on their electric bills for green power

- Utility restructuring is favored by the largest percentage of homeowners

- Most homeowners agree that "utility customers don't have enough choice in their electric service today"

- Colorado homeowner preferences mirror those expressed in national polls.

Sharing the cost of developing renewables, either through federal subsidies, rate-basing, or a combination of an electricity rate increase and green pricing, appears to be the most favored solution to the problem of funding the development of renewables. Most homeowners (81\%) are willing to pay a modestly higher electricity rate to have renewables included in the fuel source mix; the most frequently mentioned amount is $\$ 2.25$ per month. Nineteen percent say they are unwilling to pay a higher electricity rate for green power. 
Respondents were asked to assume that the use of renewable electricity would, for the immediate future, depend on the voluntary actions of electricity customers. They were asked whether they would choose to pay more for renewable electricity. Thirty-eight percent say they are likely to pay more, $21 \%$ are neutral, and $37 \%$ say they are unlikely to pay more. However, when then asked about specific amounts, $76 \%$ of the homeowners say they are willing to pay at least $\$ 1$ more per month on their electric bill to get some or all of their electricity from green power. A majority say they would pay at least $\$ 4$ more per month. The most frequently selected amount, by $20 \%$, is $\$ 5$ more per month.

A plurality of $47 \%$ of homeowners is favorable toward the idea of utility restructuring; however, respondents may not have known enough about restructuring to respond in more than a tentative manner. Reasons for favoring restructuring emphasize competition and keeping prices down. Reasons for an unfavorable response are that electricity would or could cost more.

When asked about the basis on which they would choose an electricity service provider-should they have a choice - homeowners indicate price of electricity and quality of customer service as the most important criteria. The provider's reputation is also an important choice factor. Environmental effects are viewed as important, but less so than price and service. The geographic location of the provider is not an important utility choice criterion.

Colorado utilities seem to have a relatively good reputation with their customers. Homeowners are, in general, satisfied with the service they receive. They also favor utility development of clean-coal technology to help control emissions. Widespread support exists for utilities to develop renewables as part of their electricity generating mix. However, a majority perceive reluctance on the part of their utilities to do so.

In conclusion, more-affluent, married Colorado single-family homeowners are somewhat favorable to utility restructuring; want to see green power developed; prefer to share the costs broadly by various means; are willing to pay slightly higher electricity rates to develop renewable sources of electricity; and believe that utility customers don't have enough choice in their electric service today. 


\section{Colorado Homeowner Preferences on Energy and Environmental Policy}

\section{Introduction}

A survey on energy and environmental policy was conducted in conjunction with a more comprehensive market assessment of residential grid-tied photovoltaic (GPV) systems for Colorado. Data were collected by the University of Colorado from May 1998 through July 1998. A mail questionnaire focused on important contextual issues, including broad questions concerning energy preferences, environmental concerns, and utility restructuring, as well as attitudes toward utility companies. Respondents were asked to complete this questionnaire in addition to a longer, companion questionnaire about GPV. ${ }^{1}$ The study included these additional questions to permit analysis on whether perceptions and policy preferences on energy and the environment affects homeowner interest in purchasing residential GPV. ${ }^{2}$

The questionnaire was sent to a probability sample ${ }^{3}$ of single-family homeowners in the state of Colorado. This sample was drawn from a sampling frame that included only homeowners who represent married couples with annual incomes of $\$ 50,000$ or more. The number of respondents was 206 , for a response rate of approximately $60 \%$. Based on this number of respondents, the margin of error associated with the results of any individual question is approximately $6.7 \%$.

The survey respondents (henceforth known as "the sample") are more representative of affluent, married homeowners in Colorado than of all homeowners in the state. ${ }^{4}$ In fact, $95 \%$ of them are married and $83 \%$ have annual incomes of at least $\$ 50,000 .{ }^{5}$ Seventy-six percent are male heads of households. More than half (52\%) represent two-parent families with children, and another $40 \%$ represent two-adult families (no children). The majority (54\%) are between 25 and 49 years of age, and 36\% are 50 to 64 years of age. Occupationally, 26\% describe themselves as professionals and $19 \%$ as managers or executives. Thirteen percent own their own businesses, $10 \%$ are skilled trade or craft workers, and $12 \%$ are retired. The balance work in a variety of other occupations.

Environmental concern has been increasing for many years, as shown in national poll data (Farhar 1994a, 1994b, 1996). For example, in the 1970s, opinions of national survey respondents were polarized when a trade-off was posed between adequate energy and environmental protection. About $35 \%$ were on each side of the question in 1973, and the percentage hovered around that point until 1981. Then, public opinion began to diverge and, by

${ }^{1}$ Findings from the GPV survey are reported in Farhar and Coburn (1999).

${ }^{2}$ Results from the GPV analysis are not included in this report.

${ }^{3}$ The sample was chosen using the interval selection method of systematic sampling. A commercially available sampling frame was employed.

${ }^{4}$ This sample differs significantly from the larger GPV sample in the following ways: a statistically higher percentage of respondents are married, have higher incomes, are between 50 and 64 years of age, and live in two-parent families with children. In addition, fewer are retired and fewer are age 65 or older. This sample does not differ significantly from the larger GPV sample on educational attainment, geographic area of residence in Colorado, political orientation, type of community (rural versus urban), choice of primary heating fuel, utility service territory, likelihood of moving, and lifestyle and values.

${ }^{5}$ These numbers are not each $100 \%$ owing to changes in actual respondent characteristics occurring after the point in time when the frame was constructed, and/or to initial frame inequities. 
1990, a clear majority of respondents expressed more concern for the environment than for adequate energy supplies. For the first time in two decades, survey data indicated that a majority of the population believed environmental protection laws and regulations had not gone far enough.

Trends in public opinion polls have also shown long-standing preferences for renewables and efficiency over other energy sources and usage patterns. Majorities of respondents to national polls dating back to 1979 prefer renewable energy and energy efficiency over other alternatives when cost or price are not mentioned. The pattern of preferences for using renewables to supply energy and energy efficiency to decrease demand has been consistent in the poll data for 20 years. This is one of the strongest patterns identified in all of the national poll data on energy and the environment. In addition, majorities of the respondents, ranging from $56 \%$ to $80 \%$, say they would pay a premium for environmental protection or renewable electricity.

Energy preferences and environmental concerns are linked. National survey data show that most environmental concerns - such as air pollution, oil spills, acid rain, pollution from automobiles, and the greenhouse effect-are energy related, in the minds of respondents (Cambridge Reports/Research International 1990). A 1993 survey asked whether respondents agreed with the statement that every time we use coal or oil or gas, we contribute to the greenhouse effect. Nearly two-thirds said the statement was "probably true" or "definitely true," showing awareness of a connection between energy cause and environmental effect (National Opinion Research Center 1993). Electricity customers were asked to rank energy sources used to generate electricity in terms of their perceived environmental threat (Cambridge Reports 1990). The results indicated that solar energy was perceived as least risky, followed by hydropower and natural gas. Oil, solid waste incineration, coal, and nuclear power, respectively, were perceived as the most environmentally risky sources. These and other data directly show, or imply, that the public has begun to connect energy production and use with damage to the environment (Farhar $1993 ; 1996){ }^{6}$

Attitudes toward utility companies have become more favorable than they were in the late 1970s and early 1980s, when the oil and utility price shocks occurred (Farhar 1994a). A 1989 Roper poll found that electric utilities ranked fourth on a list of 12 types of services in terms of excellence of service provided ${ }^{7}$ (Farhar 1993). The percentages of respondents assigning positive ratings to utilities have remained high in recent years. In a 1989 Roper poll, 77\% said their electric utility provided "excellent service" or "good service." In 1990, 93\% of a national sample said they were "very satisfied" or "satisfied" with public utilities, such as their gas company, electric company, or phone company. In 1992, 84\% of a national sample said they were "very satisfied" or "reasonably satisfied" with the electric company in their area (Farhar 1993).

The present study provided an opportunity to collect data to determine whether a sample of Colorado homeowners reflects the same opinions on energy and environmental policy as those expressed in national polls. In addition, it provided the chance to empirically document whether homeowners explicitly connect energy production and consumption with environmental concerns.

This report, which summarizes the findings of the perceptions and preferences of Colorado homeowners, is organized into the following five sections:

Section One: Ranking of environmental problems and the degree to which energy and environmental concerns are linked

\footnotetext{
${ }^{6}$ Studies mentioned showing national polling data are cited in Farhar $(1993,1996)$.

${ }^{7}$ Such as supermarkets, doctors, banks, phone companies, department stores, credit card companies, and mail order companies.
} 
Section Two: Preferences among energy alternatives, including perceived environmental threat of various energy sources and preferences among renewable energy sources

Section Three: Preferences between rate-basing and green-pricing approaches to paying for renewable electricity, and on state willingness to pay more for green power

Section Four: Favorability toward restructuring and utility choice criteria in a competitive environment

Section Five: Attitudes toward utility companies, including trust and criticisms, and attitudes toward utility involvement in renewables. 


\section{Section One \\ Energy and the Environment}

This section presents findings on Colorado homeowners' ranking of the importance of environmental problems.

Respondents were provided with a list of 10 environmental problems and asked:

On a 1 to 10 scale, how important do you think each of the following environmental problems is in today's world?

\section{Not at all important}

Table 1 summarizes findings on the importance assigned to these environmental problems. The table lists the mean scores from the oversample for each of the problems, as well as three associated response percentages: the percentage of respondents assigning 10 on 1-10 scale, with $1=$ "Not at all important" and $10=$ "Very important"; the percentage of respondents assigning 8, 9, or 10 ratings; and the percentage of respondents assigning ratings of $7,8,9$, or 10 . This data arrangement shows the percentages giving each environmental problem the greatest importance (the 10 rating), strong importance (an 8, 9, or 10 rating), or, simply, importance (a 7, 8, 9, or 10 rating). Environmental problems are listed in the table from high to low according to the sizes of their mean scores.

Water pollution, air pollution, and resource depletion are the three environmental problems receiving the highest scores, on average. They receive mean importance ratings of 8.0 or more, and approximately $75 \%$ of respondents assign them 8,9 , or 10 ratings.

Five environmental problems comprise a second group of problems ${ }^{8}$ receiving mean importance ratings ranging from 7.1 to 7.9. The percentage of respondents assigning the strong 8, 9, or 10 importance ratings to these five problems ranges from $49 \%$ to $63 \%$. This second group encompasses hazardous waste and radioactive waste, habitat/species loss, oil spills, and acid rain.

Mining and climate change/global warming comprise a third group of two environmental problems receiving average scores ranging from 6.4 to 6.6. The percentage of respondents assigning 8, 9, or 10 ratings to these two concerns are $42 \%$ to $47 \%$, respectively.

\footnotetext{
${ }^{8}$ Groupings of items are divided where the mean scores and percentages show natural breakpoints, and also where the mean score of the first item of the group above the break is likely to be significantly higher, statistically speaking, than the mean score of the first item of the group below the break
} 
Table 1. Perceived Importance of Environmental Problems

\begin{tabular}{|l|c|c|c|c|c|}
\hline Environmental Problems* & Mean & $\mathbf{\% 1 0}$ & $\mathbf{\% 8 , 9 , 1 0}$ & $\mathbf{\% 7 , 8 , 9 , 1 0}$ & Base $\mathbf{n}^{* * *}$ \\
\hline Water pollution & 8.8 & 48 & 83 & 92 & 199 \\
\hline Air pollution & 8.4 & 41 & 74 & 86 & 199 \\
\hline Resource depletion & 8.1 & 40 & 73 & 82 & 197 \\
\hline Hazardous/toxic waste & 7.9 & 35 & 63 & 75 & 198 \\
\hline Radioactive waste & 7.8 & 43 & 63 & 74 & 199 \\
\hline Habitat/species loss & 7.3 & 32 & 57 & 66 & 198 \\
\hline Oil spills & 7.3 & 26 & 56 & 66 & 197 \\
\hline Acid rain & 7.1 & 24 & 49 & 67 & 197 \\
\hline Mining & 6.6 & 18 & 42 & 54 & 196 \\
\hline Climate change/global warming & 6.4 & 25 & 47 & 53 & 195 \\
\hline
\end{tabular}

*Other answers volunteered by respondents included: "dependence on Middle East oil cartels" and "environmental concerns are a scare tactic."

**The term "base $\mathrm{n}$ " refers to the number used as the denominator in calculating the percentages of the respondents giving a response. It represents the number of valid responses to each item.

In summary, water and air pollution appear to be seen as the most serious environmental problems, closely followed by resource depletion. Waste problems, including both hazardous and radioactive waste, are also of concern. Interestingly, global warming is at the bottom of the list, below mining, with fewer than half of all respondents giving it a strong 8,9 , or 10 importance rating.

Respondents may not have realized that most of the environmental problems listed are energy related. They were asked this question in anticipation of that possibility:

On a 1 to 10 scale, to what extent do you feel our environmental problems are related to energy production and use? [Please circle one response.]

\section{Not \\ related}

1
2

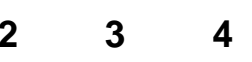

\section{5}

\section{Strongly related}

Don't know 
The mean score is 6.8, indicating that respondents believe environmental problems are somewhat related to energy, but not strongly so. Forty-five percent indicate a strong 8, 9, or 10 relationship, and $62 \%$ assign relationship ratings of $7,8,9$, or 10 . Table 2 contains more information pertaining to this question.

Table 2. Linkage of Energy with the Environment

\begin{tabular}{|l|l|}
\hline $\begin{array}{l}\text { To what extent do you feel our environmental problems are related to } \\
\text { energy production and use? }\end{array}$ & $\%$ \\
\hline Response categories & 62 \\
\hline Related (7-10) & 17 \\
\hline Neutral (5-6) & 16 \\
\hline Not related (1-4) & 6 \\
\hline Don't know & $101 *$ \\
\hline Total & 198 \\
\hline Base n & \\
\hline *Percentages do not add to 100 because of rounding. \\
\hline
\end{tabular}

In summary, most of today's global environmental problems perceived as important by a majority of Colorado homeowners are energy related. When asked directly, a majority of respondents indicate that energy and our environmental problems are, indeed, related. 


\section{Section Two Comparative Energy Preferences}

This section presents findings on homeowner preferences among energy alternatives, including the perceived environmental threat of various energy sources and preferences among renewable energy sources.

\section{Perceived Environmental Threat of Various Energy Sources}

Respondents were asked two questions about perceptions of various energy sources. The first of these was:

Listed below are several energy sources that are used to generate electricity. As you read each one, please circle any number from 1 to 10, where 1 means "no environmental threat, " and 10 means "a large environmental threat" to show how much of an environmental threat you think that energy source is when used to generate electricity. [Please circle one response.]

\section{No environ- mental threat}

$$
1
$$

\section{Large environ- mental threat}

Don't

know

Table 3 and Figure 1 summarize findings on the perception of environmental threat associated with eight specific sources of electricity. The table lists the mean score from the sample for each of eight electricity sources, as well as three associated response percentages: the percentage of respondents assigning "10" on 1-10 scale, with $1=$ "No environmental threat" and $10=$ "Large environmental threat"; the percentage of respondents assigning 8 , 9 , or 10 ratings; and the percentage of respondents assigning ratings of $7,8,9$, or 10 . This data arrangement shows the percentages giving each electricity source the greatest importance (the 10 rating), strong importance (an 8,9 , or 10 rating), or, simply, importance (a 7, 8, 9, or 10 rating). Electricity sources are listed in the table from high to low according to the sizes of their mean scores.

Nuclear energy, coal, and oil are considered the electricity sources with the largest environmental threat. They receive mean importance ratings of 7.0 or higher, and two of them are assigned 8, 9, or 10 ratings by approximately half of the respondents. Solid waste incineration, natural gas, and hydropower comprise a second group of three electricity sources that are not regarded as highly threatening, receiving mean importance ratings ranging from 3.9 to 5.5. The percentages of respondents assigning these sources strong 8 , 9, or 10 importance ratings range from $11 \%$ to $23 \%$. Solar and wind are perceived as the least environmentally threatening sources. These two electricity sources have very low average scores, ranging from 1.7 to 1.9. The percentage of respondents assigning 8,9 , or 10 ratings is only approximately $1 \%$ for each source. 
Table 3. Perceived Environmental Threat of Various Sources of Electricity

\begin{tabular}{|l|c|c|c|c|c|}
\hline Electricity Source & Mean & $\mathbf{\% 1 0}$ & $\mathbf{\% 8 , 9 , 1 0}$ & $\mathbf{\% 7 , 8 , 9 , 1 0}$ & Base n \\
\hline Nuclear energy & 7.2 & 32 & 52 & 65 & 201 \\
\hline Coal & 7.1 & 18 & 51 & 67 & 199 \\
\hline Oil & 7.0 & 15 & 49 & 64 & 197 \\
\hline Solid waste incineration & 5.5 & 8 & 23 & 32 & 178 \\
\hline Natural gas & 4.4 & 3 & 11 & 16 & 195 \\
\hline Hydropower & 3.9 & 2 & 10 & 16 & 197 \\
\hline Solar & 1.9 & 1 & 1 & 1 & 199 \\
\hline Wind & 1.7 & 1 & 1 & 1 & 201 \\
\hline
\end{tabular}

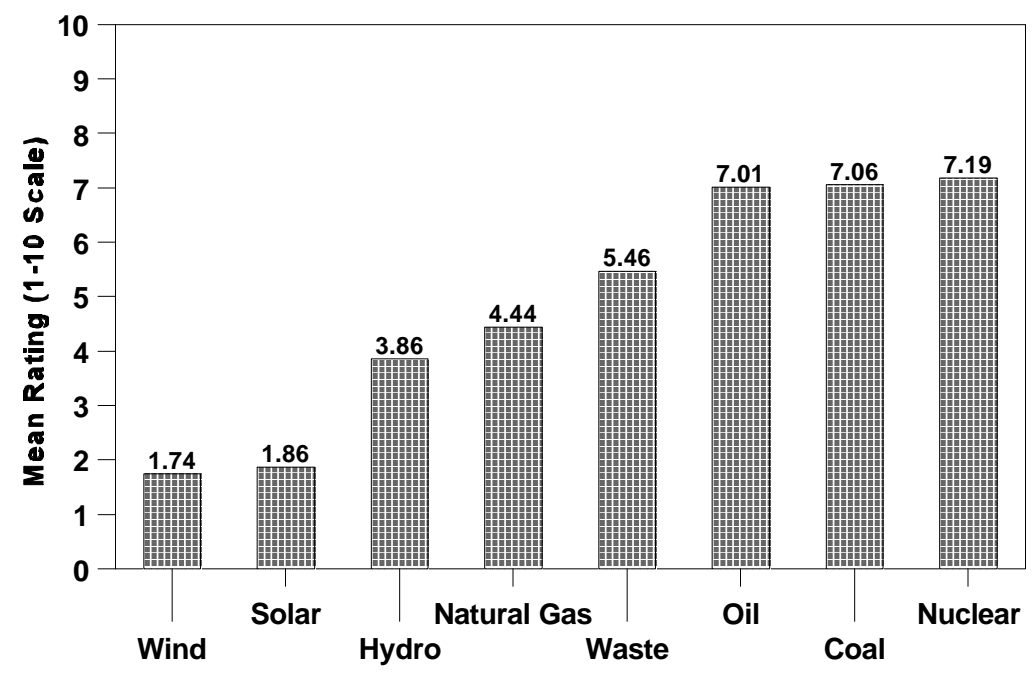

Figure 1. Perceived Environmental Threat of Various Sources of Electricity 


\section{Perceived Characteristics of Energy Sources}

The second question on comparative energy preferences, modeled after a national poll question, was:

Which source of electricity do you think of most when you read each of the following phrases? [For each phrase, please circle only one energy source.]

Responses about six electricity sources mentioned were solicited: coal, hydropower, natural gas, nuclear, oil, and solar and wind. Respondents were asked to select one of the six sources for each of the listed characteristics. The numbers in parenthesis are the percentage of respondents choosing "solar and wind". 9

- Best for the environment (79\%)

- $\quad$ Safest $(70 \%)$

- Most abundant (43\%)

- Makes the U.S. most self-reliant (45\%)

- Least expensive (24\%)

- Will help the most in meeting growing demands for energy (41\%)

- Stimulates economic development the most (24\%)

- Diversifies and extends our energy mix the most (52\%)

- Improves the quality of our air the most (80\%)

- Adds the most new high technology jobs (40\%)

- Use of this energy source will increase the most in the 21 st century (60\%)

- Best for the U.S. economy (32\%)

- Most positive for you (51\%).

Table A-1 in Appendix A contains information about the responses to these items. Surprisingly, the highest percentage of respondents identifies solar and wind as the resource most closely tied to every one of the 13 characteristics listed. Although it might be expected that $79 \%$ would indicate that solar and wind are best for the environment, it is more surprising that solar and wind are also selected-more often than the other power sources - as the resource that makes the U.S. most self-reliant, is most abundant, is best for the economy, and is least expensive. The pattern of findings is similar to that from national poll data.

Particularly large percentages of respondents linked solar and wind with four specific characteristics: improves the quality of our air the most (80\%), safest (70\%), use will increase the most in the 21 st century (60\%), and diversifies and extends our energy mix the most (52\%). Other energy sources are not as highly regarded. For many of the characteristics, the least frequently selected sources are fossil fuels. Although nuclear power is selected more often than fossil fuels on all 13 characteristics, nuclear's frequency of selection does not approach that of solar and wind power. ${ }^{10}$

These findings corroborate those from other studies in which majorities of respondents in national and local-area samples select renewables as the preferred energy source when respondents are presented with a list of conventional and renewable power sources on which to express their preferences.

\footnotetext{
${ }^{9}$ Not all potential characteristics of electricity sources were included in this list, nor was energy efficiency included as part of the energy supply options listed.

${ }^{10}$ Although solar and wind power are selected most frequently among energy alternatives on each characteristic, the most frequently occurring response for two of the characteristics-35\% for stimulates economic development the most and 33\% for best for the economy — was "don't know."
} 


\section{Preferences among Renewable Energy Alternatives}

Energy specialists and utility staff are often faced with the problem of deciding which renewable resources would be welcomed, or at least accepted, by their customers. A question was included in the survey to help address this problem.

Listed below are a number of energy sources often thought of as renewable. Of these choices, which three do you think would be best to use for meeting energy needs in Colorado? [Please rank your top three choices, with 1 as your first choice, 2 as your second choice, and 3 as your third choice.]

The choices, listed in the following order, were: biomass power (burning forest or agricultural waste, or energy crops); burning municipal solid waste; geothermal (heat from within the Earth's crust); ground-source heat pumps; small-scale hydropower; large-scale hydropower; landfill gas; passive solar houses; solar cells (photovoltaics/PV) for electricity; active solar (solar domestic hot water systems); wind power. ${ }^{11}$

Table 4 contains information about the responses to this question. The top-ranked renewable energy sources for Colorado are solar cells $(P V)$ for electricity, selected by $33 \%$ of respondents as their first choice; wind power, selected by $14 \%$ as their first choice; passive solar houses, selected by $12 \%$ as their first choice; and active solar, selected by $7 \%$ as their first choice. Biomass power $(1.5 \%)$ and ground-source heat pumps $(0.5 \%)$ are selected least often as a first choice on this list.

In summary, the electricity sources perceived as least environmentally threatening — solar and wind — are also the most preferred. In addition to their environmental benefits, solar and wind are preferred over other electricity sources for other positive attributes, such as safety, economic benefits, and self-reliance and diversity of U.S. energy supply.

\footnotetext{
${ }^{11}$ Responses to this questions could have been influenced by the fact that the questionnaire was included in a package with the questionnaire on grid-tied photovoltaics.
} 
Table 4. Top-Ranked Renewable Energy Sources for Colorado

\begin{tabular}{|c|c|c|c|}
\hline \multicolumn{4}{|c|}{$\begin{array}{l}\text { Listed below are a number of energy sources often thought of as renewable. Of these choices, } \\
\text { which three do you think would be best to use for meeting energy needs in Colorado? }\end{array}$} \\
\hline Renewable energy source & $\begin{array}{c}\text { 1st } \\
\text { choice } \\
\%\end{array}$ & $\begin{array}{c}\text { 2nd } \\
\text { choice } \\
\%\end{array}$ & $\begin{array}{c}\text { 3rd } \\
\text { choice } \\
\%\end{array}$ \\
\hline $\begin{array}{l}\text { Solar cells (photovoltaic/PV for } \\
\text { electricity) }\end{array}$ & 33 & 19 & 15 \\
\hline Wind power & 14 & 22 & 25 \\
\hline $\begin{array}{l}\text { Active solar (solar domestic hot } \\
\text { water systems) }\end{array}$ & 7 & 17 & 11 \\
\hline Passive solar houses & 12 & 10 & 10 \\
\hline Large-scale hydropower & 9 & 8 & 7 \\
\hline Burning municipal solid waste & 7 & 6 & 8 \\
\hline Small-scale hydropower & 6 & 6 & 5 \\
\hline $\begin{array}{l}\text { Geothermal (heat from within } \\
\text { the Earth's crust) }\end{array}$ & 6 & 4 & 6 \\
\hline Landfill gas & 2 & 1.5 & 6 \\
\hline $\begin{array}{l}\text { Biomass power (burning forest } \\
\text { or agricultural waste, or energy } \\
\text { crops) }\end{array}$ & 1.5 & 2.5 & 3 \\
\hline Ground-source heat pumps & 0.5 & 3.5 & 2 \\
\hline Other* & 2 & 0.5 & 2 \\
\hline Total & 100 & 100 & 100 \\
\hline Base $n$ & 197 & 192 & 187 \\
\hline
\end{tabular}




\section{Section Three Rate-Basing Versus Green Pricing}

This section discusses preferences between two different ways of paying for renewable electricity: (1) rate-basing, a situation in which all electricity customers pay a slight increase in electricity rates, and (2) green-pricing, a situation in which only those customers who are actually interested in renewables pay more. The section also covers the survey respondents' stated willingness to pay more for green power under each of these scenarios.

A key policy question is the extent to which electricity customers are willing to absorb in their utility bills the cost of developing renewables. In the United States, customers wanting their utility companies to add renewables to their power-generating mix have been asked to voluntarily pay an extra amount each month on their utility bills through green-pricing programs. ${ }^{12}$ Utility Companies do not want the costs of renewable generation to become stranded if electricity markets open up to competition, and price is the only criterion on which they are competing.

In parts of the country where utilities have offered these programs, $1 \%-2 \%$ of customers have immediately volunteered to pay an extra charge on their electric bill to cover the costs of centralized green power. The amount paid has averaged between $\$ 2.50$ and \$5.00 per month (Farhar and Houston 1996; Holt 1998; Farhar 1999). Because these programs are relatively new, their track record of participation over time is not yet established.

The present survey included four key questions related to this issue. The first question was:

Electricity from renewables costs more than electricity from conventional energy sources. However, some argue that using renewables benefits everyone. If utilities were to develop renewables as part of their power mix, how should the cost be paid for? [Please check one response.]

Although no single approach would satisfy everyone, taken together, the response categories show broad-based support for renewables development received majority support. Table 5 reports the findings. The modal response, selected by $29 \%$, is that the federal government should subsidize power generation from renewables just as it subsidizes power generation from other fuels. This result is particularly interesting because most respondents describe themselves as politically conservative (mean score of 4.53 on a 1-10 scale, where 1 was "Very conservative" and 10 was "Very liberal").

The next most frequently mentioned response, selected by $25 \%$ of respondents, is that everyone's rates should be increased slightly (rate basing). A slightly lower percentage of respondents, $21 \%$, indicate that only those who choose renewable sources should pay (green pricing). Eighteen percent indicate that renewables should be paid for both by a slight increase for everyone and voluntary contributions of those specifically choosing them. Finally, $3 \%$ say that renewables should not be developed, and $4 \%$ give other responses. ${ }^{13}$

\footnotetext{
${ }^{12}$ The situation in California, which has statewide utility restructuring, is different. Electricity customers there can choose to purchase their electricity from a renewable electricity provider.

${ }^{13}$ Other responses, mentioned by seven respondents, included "will reduce profits" and "should not drive up costs to customers."
} 
Table 5. Rate Basing versus Green Pricing

\begin{tabular}{|l|c|}
\hline $\begin{array}{l}\text { Electricity from renewables costs more than electricity from conventional energy sources. However, } \\
\text { some argue that using renewables benefits everyone. If utilities were to develop renewables as part of } \\
\text { their power mix, how should the cost be paid for? }\end{array}$ \\
\hline Response categories & $\%$ \\
\hline $\begin{array}{l}\text { The federal government should subsidize power generation from renewables just } \\
\text { as it subsidizes power generation from other fuels }\end{array}$ & 29 \\
\hline Everyone's rates should be increased slightly & 25 \\
\hline Only those who choose renewable sources should pay & 21 \\
\hline $\begin{array}{l}\text { Both (a slight rate increase for everyone, plus those who specifically choose } \\
\text { renewable sources should be charged more) }\end{array}$ & 18 \\
\hline Other & 4 \\
\hline Should not develop renewables as part of the utility power mix & 3 \\
\hline Total & 100 \\
\hline Base $\mathrm{n}$ & 201 \\
\hline
\end{tabular}

\section{Willingness to Pay a Slightly Higher Electricity Rate (Rate-Basing)}

The second question focused on willingness to pay for an electricity rate increase (rate-basing) to cover the cost of renewables development. Respondents were asked:

If everyone were to pay a slight increase in electricity rates to develop renewable sources of electricity, what is the most you would be willing to pay? [Please check one response.]

Response options were given in percentages and the equivalent dollar amount per month, based on a typical monthly electric bill of $\$ 45$. These were:

- $1 / 2 \%$ more (about $23 \notin$ per month on a typical residential bill)

- $1 \%$ more (about $45 \phi$ per month)

- $2 \%$ more (about $90 \notin$ per month)

- $5 \%$ more (about $\$ 2.25$ per month)

- $10 \%$ more (about $\$ 4.50$ per month)

- 0 - Not willing to pay more.

Provided everyone pays, most respondents (79\%) say they are willing to pay a higher monthly electricity rate. Figure 2 and Table A-2 in Appendix A present the data from this question. The most frequently specified amount is $5 \%$ more, or $\$ 2.25$ per month. Almost one in five respondents (19\%) indicate they would be willing to pay $10 \%$ more, or $\$ 4.50$ per month. Cumulatively, more than one-third (35\%) say they would pay between $23 \phi$ and $90 \phi$ more per month for renewable electricity development, and $79 \%$ indicate they would be willing to pay an incremental amount. 


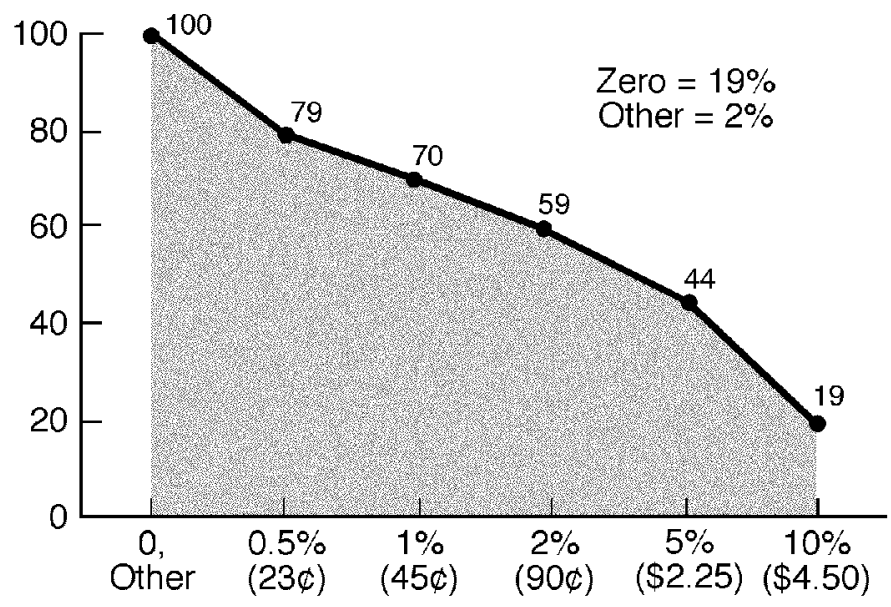

Incremental Amount per Month Willing to Pay

$02618010 \mathrm{~m}$

Figure 2. Incremental Monthly Amount Respondents Are Willing to Pay Under a Rate-Basing Program to Develop Renewable Forms of Energy (Cumulative)

\section{Stated Likelihood of Voluntarily Paying More for Green Power (Green Pricing)}

The third question asked how likely people would be to voluntarily pay more for green pricing. The question was phrased:

Assume that for the immediate future, the use of renewable electricity sources will depend on the voluntary actions of electricity customers. If paying for renewable electricity were offered on a voluntary basis, how likely would you be to pay more money on a monthly basis to get some or all of your electricity from renewables? Would you say ... ? [Please circle one response.]

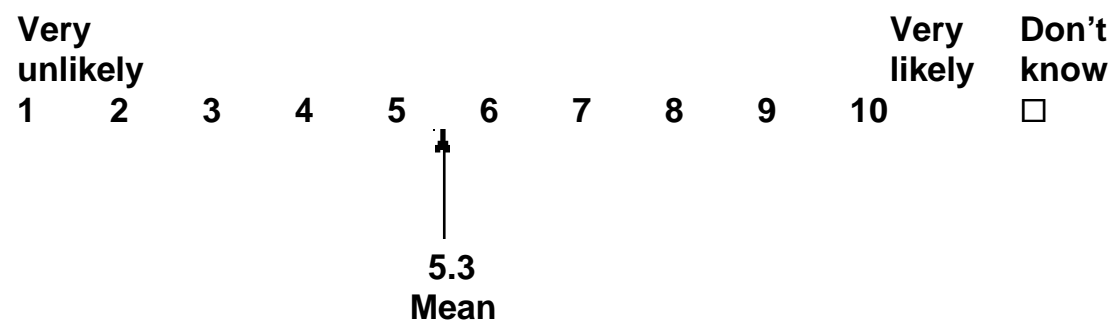

The mean score is 5.3 on the 10-point scale. Willingness to pay more for green pricing is polarized: $38 \%$ of respondents indicate they are likely to pay more $(7,8,9$, or 10 on a 10-point scale) and $37 \%$ indicate they are unlikely to do so $(1,2,3$, or 4 on a 10 -point scale). More than one in five (22\%) indicate a neutral or mixed position ( 5 or 6 on the scale), and $4 \%$ say they don't know. Table 6 presents the findings. 


\section{Table 6. Likelihood of Paying More for Green Power in a Green-Pricing Program}

\begin{tabular}{|l|c|}
\hline $\begin{array}{l}\text { Assume that for the immediate future, the use of renewable electricity sources will depend } \\
\text { on the voluntary actions of electricity customers. If paying for renewable electricity were } \\
\text { offered on a voluntary basis, how likely would you be to pay more money on a monthly } \\
\text { basis to get some or all of you electricity from renewables? Would you } \\
\text { say...? }\end{array}$ & $\%$ \\
\hline Response categories & 38 \\
\hline Likely (7-10) & 22 \\
\hline Neutral/mixed (5-6) & 37 \\
\hline Unlikely (1-4) & 4 \\
\hline Don't know & $101 *$ \\
\hline Total & 200 \\
\hline Base n & \\
\hline *Percentages do not add to 100 because of rounding. & \\
\hline
\end{tabular}

\section{Willingness to Voluntarily Pay More for Green Power (Green Pricing)}

The final question in this series queried respondents on the actual additional amount they would be willing to pay (assuming they were willing to pay anything) under a green-pricing program. The question was:

At this time, how much more would you choose to pay on your electric bill each month to ensure that some or all of your electricity comes from renewable sources? [Please check one response.]

More than three-quarters (76\%) of respondents say they were willing to pay an incremental amount ranging from $\$ 1$ per month to more than $\$ 10$ per month on their electric bill for renewable electricity. Almost a quarter (24\%) of respondents say they are unwilling to pay anything more. The most frequently indicated amount, selected by $20 \%$ of respondents, is $\$ 5$ more per month. Figure 3 and Table A-3 in Appendix A present the findings.

Table 6 shows that $37 \%$ say they are unlikely to pay more on a voluntary basis to get some or all of their electricity from renewable sources. Table A-3 shows that only $24 \%$ say they would not choose to pay more for green power. This shows that $13 \%$ changed their minds in a direction positive toward green pricing when they saw the question mentioning relatively modest amounts for green pricing; for example, $\$ 1, \$ 2$, or $\$ 3$ more per month. This suggests that approximately three in four homeowners would state they are willing to pay at least a modest incremental amount on their utility bill, and that almost four in ten homeowners would be likely to actually do so. 


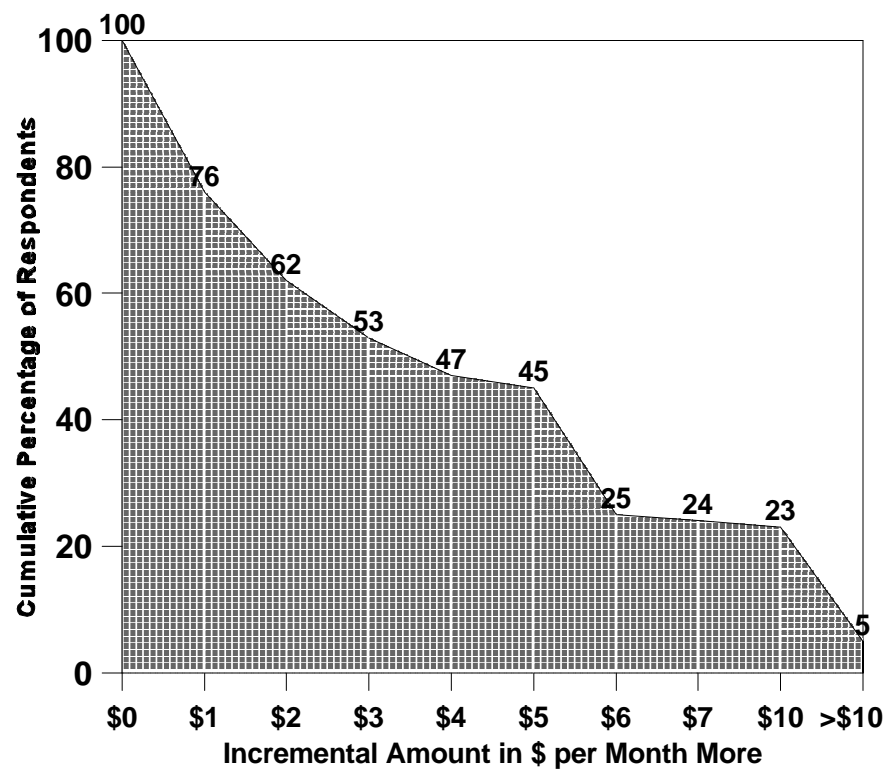

Figure 3. Incremental Monthly Amount Respondents Are Willing to Pay Voluntarily under a Green-Pricing Program (Cumulative)

\section{Summary}

In summary, the sample tends to favor paying for the development of renewables either through a federal subsidy or through a slight electricity rate increase. Respondents are polarized on how likely they would be to actually pay anything more for voluntary green pricing programs, with approximately $40 \%$ indicating that it is likely they would pay more, and approximately the same percentage indicating that it is unlikely they would actually pay anything more. However, when asked about a specific amount, the percentage indicating a willingness to pay something more per month for green power reaches $76 \%$ willing to pay at least $\$ 1$ per month more. 


\section{Section Four \\ Utility Restructuring}

This section presents findings on homeowner favorability toward restructuring and preferred utility choice criteria in a competitive utility environment.

Because respondents might not be familiar with the concept of utility restructuring, the questions about this topic were preceded with a paragraph-long explanation, as follows.

Following are two questions about electricity sources and ways in which electricity is distributed.

Currently, Coloradans are not able to choose their electric service provider. In any community, only one power company provides electricity. Policy makers are considering opening the generation of electric power to competition, allowing customers to choose the power generating company they want to use. The process would be similar to the way consumers can now choose among long-distance providers. However, the company that owns and operates the utility grid (electric lines, towers, and substations) would remain a regulated monopoly. How do you feel about this idea of "restructuring" electricity power production and giving customers a choice? How favorable are you to the idea of electric utility restructuring? [Please circle one response.]

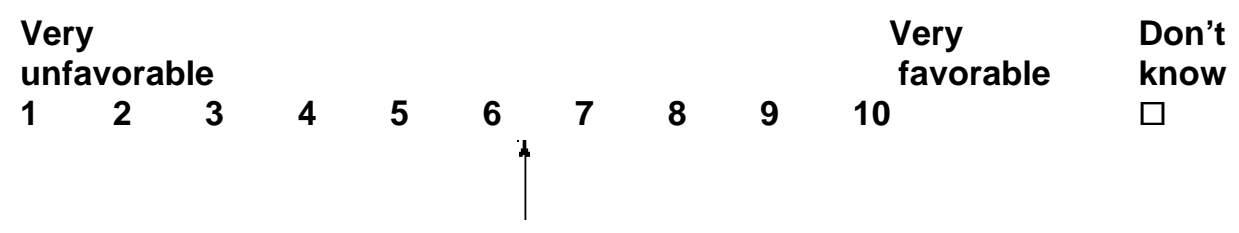

\section{1}

\section{Mean}

A 1-10 scale, ranging from "Very unfavorable" to "Very favorable," provided the response options. The overall mean score is somewhat though not strongly, favorable at 6.14 . Table 7 summarizes the responses. Twenty-six percent of respondents give restructuring a very favorable (9-10) rating, $21 \%$ a favorable (7-8) rating, $16 \%$ a neutral (5-6) rating, $10 \%$ an unfavorable (3-4) rating, and $18 \%$ a very unfavorable (1-2) rating. Ten percent of the respondents say they don't know. 
Table 7. Favorability toward Utility Restructuring

\begin{tabular}{|l|c|}
\hline Responses (1-10 scale)* & \% \\
\hline Very favorable (9-10) & 26 \\
\hline Favorable (7-8) & 21 \\
\hline Middle-of-the-road (5-6) & 16 \\
\hline Unfavorable (3-4) & 10 \\
\hline Very unfavorable (1-2) & 18 \\
\hline Don't know & 10 \\
\hline Total & $101 * *$ \\
\hline Base $\mathrm{n}$ & 199 \\
\hline $\begin{array}{l}* \text { Mean score }=6.14 . \\
* * \text { Percentages do not add to } 100 \text { because of rounding. }\end{array}$ \\
\hline
\end{tabular}

Reasons mentioned most frequently for a favorable response are competition keeps costs and prices down (25\% of respondents say this) and competition is the American way (8\%). Reasons mentioned most frequently for an unfavorable response toward utility restructuring are that electricity would or could cost more, phone restructuring has been a mess for consumers, and worry about service and interrupted power supply (Table A-4 in Appendix A).

Respondents were asked:

If it came to pass that customers could choose their electricity provider, on a scale of 1 to 10, how important would each of the following be in your choice?

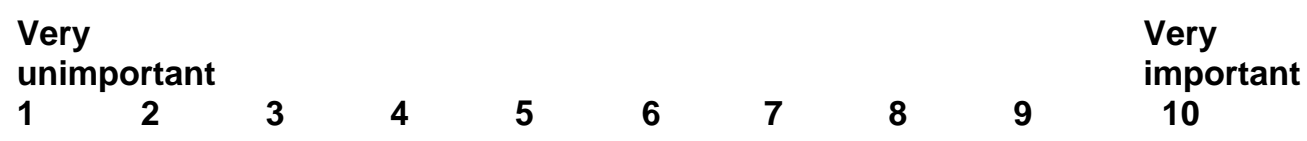

Respondents were asked to rate each of the following characteristics: price of the electricity offered by the provider, environmental effects of producing the electricity, quality of customer service, reputability of the company, and geographic location of the company.

The three criteria receiving the highest mean scores are price of electricity, (mean score of 9.0; $86 \%$ of respondents assign it a strong 8,9 , or 10 rating), quality of customer service (mean score of $8.87 ; 86 \%$ rate it as 8,9 , or 10), and reputability of the company (mean score of $8.43 ; 78 \%$ rate it as 8,9 , or 10). Environmental effects of producing the electricity receives a lower mean score of $7.64 ; 62 \%$ rate it as 8,9 , or 10), along with geographic location (mean score of $5.12 ; 26 \%$ rate it as 8,9 , or 10). Table 8 presents more information concerning this question. 
Table 8. Importance of Utility Choice Criteria

\begin{tabular}{|c|c|c|c|c|c|}
\hline Utility choice factor & $\begin{array}{l}\text { Mean } \\
\text { score }\end{array}$ & $\% 10$ & $\% 8,9,10$ & $\% 7,8,9,10$ & $\begin{array}{l}\text { Don't } \\
\text { know }\end{array}$ \\
\hline $\begin{array}{l}\text { Price of electricity offered by the } \\
\text { provider }\end{array}$ & 9.0 & 55 & 86 & 94 & -- \\
\hline $\begin{array}{l}\text { Environmental effects of } \\
\text { producing the electricity }\end{array}$ & 7.64 & 29 & 61 & 75 & 1 \\
\hline Quality of customer service & 8.87 & 50 & 86 & 92 & 0.5 \\
\hline Reputability of the company & 8.43 & 44 & 78 & 85 & -- \\
\hline $\begin{array}{l}\text { Geographic location of the } \\
\text { company }\end{array}$ & 5.12 & 10 & 25 & 33 & 2 \\
\hline
\end{tabular}

In summary, the largest percentage is positive toward the idea of utility restructuring; however, it is possible that respondents may not know enough about restructuring to respond in more than a tentative manner. Price of electricity and quality of customer service appear to be important criteria for choosing an electricity provider, along with the provider's reputability. Environmental effects are also apparently important, but less so than price and service. The geographic location of the provider is apparently not an important choice criterion. 


\section{Section Five Attitudes toward the Utility}

This section discusses the survey's findings on attitudes toward the utility company, including trust in the utility, criticisms of utility operations, and attitudes toward utility involvement in the use of renewables to generate electricity.

A series of statements measured attitudes toward the utility company, including attitudes about the involvement of the utility company in developing renewable electricity. A list of 17 attitude items was preceded by the following statement:

\section{Finally some statements about your utility company...}

Please give us your opinion on the following statements concerning your utility company and renewable electricity. Would you say you agree or disagree with the following statements? [For each statement, please circle one response.]

The statements represent three different categories: (1) trust in the utility company, (2) criticisms of the utility company, and (3) attitudes toward utility involvement in renewables.

\section{Trust in the Utility Company}

Evidence from other polls suggests that those individuals more trusting of their utility company are more likely to participate in a green-pricing program. Consequently, this characteristic was felt to be an important one to evaluate in the present study. Trust was measured by five statements in the questionnaire, about which respondents were asked to express their degree of agreement. In general, $74 \%$ of respondents agree that they are very satisfied with the service they receive from their utility company. A majority (59\%) agrees that their utility company should focus its efforts on developing clean-coal technologies in order to reduce emissions. Less confidence is expressed in the utility making good decisions on the selection and development of new power sources (44\% of respondents agreeing and $23 \%$ disagreeing). Similarly, fewer respondents agree with the statement that all they wanted was reliable power at the lowest rate possible (43\% agree and $25 \%$ disagree). Finally, a majority of respondents (54\%) disagree with the statement that it makes no difference to them how their utility company generates electricity. Table A-5 in Appendix A presents the findings on these questions.

\section{Criticisms of the Utility Company}

Six statements measured the level of criticism or skepticism about the utility company. Fewer respondents agree with the statements in this category than with those in the other two categories. A majority (53\%) agrees that utility customers don't have enough choice in their electric service today. Likewise, a majority (57\%) also agrees that their utility company will be forced to use renewable sources of energy-they will have no choice. Forty-six percent agree that their utility is only driven by bottom-line profitability.

Pluralities disagree with the following statements: my utility company is not environmentally concerned (49\% disagree), I am skeptical about the accuracy of the utility billing system (47\% disagree), and I doubt that my utility company has any real commitment to renewable energy (41\% disagree). However, approximately $25 \%$ agree with these statements. Table A-6 in Appendix A presents the findings on these questions. 


\section{Utility Involvement in Renewables}

To further explore respondent support for the idea of Colorado utilities developing renewable resources to include in their electricity generating mix, the following question was asked:

Many electric utilities in Colorado are considering the addition of renewables as one of the sources from which electricity will be generated. Even though the cost is higher right now, adding these resources might make sense for long-term environmental, economic, and resource planning reasons. How do you feel about this? How favorable are you to adding renewable power sources? [Please circle one response.]

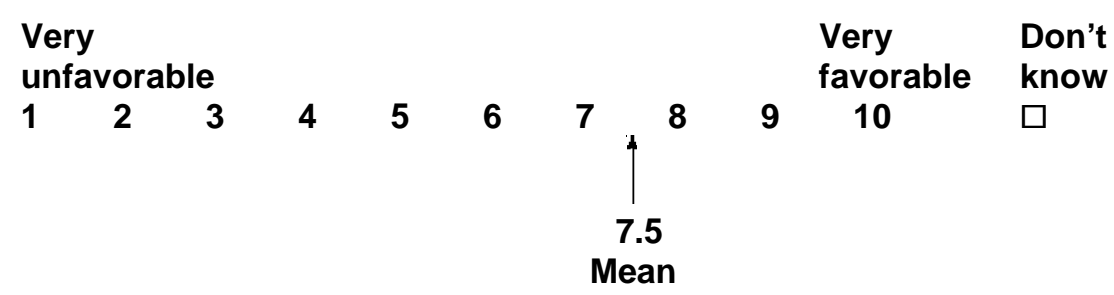

The mean response is favorable (a mean score of 7.5 on the 10-point scale). Twenty-four percent indicate a rating of $10 ; 62 \%$ indicate a strongly favorable 8,9 , or 10 response, and $70 \%$ were favorable at $7,8,9$, or 10 ratings (Table A-7 in Appendix A).

Respondents were then asked why they took the position they did (Table A-7). Among those assigning favorable ratings $(70 \%)$, the most frequently mentioned reasons are good for the environment and helps to conserve natural resources. Also frequently mentioned are will need these alternatives for future energy needs and benefits future generations. Among those regarding adding renewables unfavorably, the most frequently mentioned reason is would cost too much.

Attitudes toward utility involvement in renewables were also measured by six statements. Most respondents (77\%) agree that they want their utility company to look for new technologies and sources for generating electricity. Similarly, $76 \%$ agree that they believe their utility should take some of the risk in developing renewable energy sources. Two-thirds agree that they are favorable towards their utility's involvement with developing renewable sources for generating electricity. However, only $44 \%$ agree that their utility company is responsible for developing renewable energy sources. Forty-two percent agree that they would like to be $a$ team player with their utility company in renewable energy. Most (62\%) understand that their utility needs to make profit a priority when developing alternative energy sources. Table A-8 presents the findings.

In summary, Colorado utilities seem to have a relatively good reputation with their customers. Homeowners are, in general, satisfied with the service they receive. They also tend to favor utility development of clean-coal technology to help control emissions. Widespread support exists for utilities to develop renewables as part of their electricity generating mix. However, respondents are somewhat divided on how trustworthy they think their utility might be in actively developing renewables. 


\section{Conclusions}

More affluent, married Colorado homeowners mirror national trends in preferring renewable energy over conventional energy sources. They view nuclear, coal, and oil as posing serious environmental threats when used to produce electricity. Homeowners regard solar power and wind power as best for the environment.

Solar power and wind power are also ranked highest among all suggested electricity sources on a number of other factors, including safety, cost, abundance, national self-reliance, meeting growing energy demands, stimulating economic development, diversifying our energy mix, adding high-tech jobs, and improving our economy.

When asked to rank 11 renewable energy sources for development in Colorado, homeowners most frequently select PV and wind power as their first choice, along with passive solar.

Homeowners favor sharing the cost of developing renewables broadly, either through federal subsidies or slight increases in electricity rates. Most homeowners (79\%) are willing to pay modest incremental amounts per month on their electric bills to develop green power. When it comes to voluntary green pricing programs, approximately $40 \%$ indicate they are likely to pay something more to ensure that part or all of their electricity comes from green power. But, when asked about specific incremental amounts ranging from $\$ 1$ to more than $\$ 10$ a month, a majority (76\%) are willing to pay at least $\$ 1$ more per month for renewable power.

A plurality of $47 \%$ of the sample is favorable toward the idea of utility restructuring; however, respondents may not know enough about restructuring to respond in more than a tentative manner. Reasons given for favoring restructuring emphasize competition and keeping prices down. Reasons given for unfavorable responses are that electricity would or could cost more.

Colorado utilities enjoy a high level of customer satisfaction. At the same time, most homeowners seem to want their utilities to do more, such as investing in the development of green power.

In conclusion, more-affluent, married Colorado single-family homeowners are somewhat favorable toward utility restructuring; want to see green power developed; prefer to share the costs broadly either through tax subsidies

or modest electric rate increases; and believe that utility customers don't have enough choice in their electric service today.

More research will be needed to characterize the perceptions and preferences of all Colorado electricity customers on energy and environmental policy. 


\section{References}

Dillman, Don A. 1978. Mail and Telephone Surveys: The Total Design Method. New York: John Wiley and Sons, $325 \mathrm{pp}$.

Dillon, William R. and Matthew Goldstein. 1984. Multivariate Analysis: Methods and Applications. New York: John Wiley \& Sons, 587 pp.

Farhar, Barbara C. 1996. "Energy and the Environment: The Public View." Renewable Energy Policy Project (REPP) Issue Brief, No. 3, College Park: University of Maryland, October, 20 pp.

Farhar, Barbara C. 1994a. "Trends: Public Opinion about Energy." Public Opinion Quarterly, Vol. 58, No. 4, pp. 603-632.

Farhar, Barbara C. 1994b. "Trends in U.S. Public Perceptions and Preferences on Energy and Environmental Policy." Annual Review of Energy and the Environment. Vol. 19, pp. 211-239.

Farhar, Barbara C. 1993. Trends in Public Perceptions and Preferences on Energy and Environmental Policy. NREL/TP-461-4857. Golden, CO: National Renewable Energy Laboratory, 376 pp.

Farhar, Barbara C. 1999. Willingness to Pay for Renewable Electricity: A Review of Utility Market Research. NREL/TP-550-26148. 4/15/99 Review Draft, 24 pp.

Farhar, Barbara C. and Timothy C. Coburn. 1999. A Market Assessment of Residential Grid-Tied PV Systems in Colorado. NREL/TP-550-25283. Golden, CO: National Renewable Energy Laboratory. (In press.)

Farhar, Barbara C. and Ashley Houston. 1996. Willingness to Pay for Electricity from Renewable Energy, NREL/TP-460-21216, Golden, CO: National Renewable Energy Laboratory, September, 26 pp.

Farhar-Pilgrim, Barbara C. and Charles T. Unseld. 1982. America's Solar Potential: A National Consumer Study. New York: The Free Press, 438 pp.

Glaser, Barney and Anselm Strauss. 1967. The Discovery of Grounded Theory: Strategies for Qualitative Research. Chicago: Aldine Publishing Company, 271 pp.

Kinnear, Paul R. And Colin D. Gray, SPSS for Windows Made Simple, 2nd Edition, East Sussex, UK: Psychology Press. 386 pp.

Merton, Robert. 1990. The Focused Interview: A Manual of Problems and Procedures. 2nd Edition. New York: The Free Press, 200 pp.

Rogers, Everett M. 1995. Diffusion of Innovations. Fourth Edition. New York: The Free Press, 519 pp.

Rogers, Everett M. and F. Floyd Shoemaker. 1971. Communication of Innovations. 2nd Edition, New York: The Free Press, 476 pp. 
Appendix A. Tables 
Table A-1. Perception of Electricity Sources

\begin{tabular}{|c|c|c|c|c|c|c|c|c|c|}
\hline Phrase & $\begin{array}{c}\text { Coal } \\
\%\end{array}$ & $\begin{array}{c}\text { Hydro- } \\
\text { power } \\
\%\end{array}$ & $\begin{array}{c}\text { Natural } \\
\text { gas } \\
\%\end{array}$ & $\begin{array}{c}\text { Nuclear } \\
\text { power } \\
\%\end{array}$ & $\begin{array}{l}\text { Oil } \\
\%\end{array}$ & $\begin{array}{c}\text { Solar } \\
\text { and wind } \\
\%\end{array}$ & $\begin{array}{l}\text { Don't } \\
\text { know }\end{array}$ & Totals & Base $\mathbf{n}$ \\
\hline Best for the environment & -- & 9 & 6 & 3 & 1 & 79 & 2 & 100 & 204 \\
\hline Safest & 1 & 17 & 5 & 2 & $--*$ & 70 & 5 & 100 & 202 \\
\hline Most abundant & 21 & 8 & 15 & 7 & -- & 43 & 6 & 100 & 202 \\
\hline Makes the U.S. most self-reliant & 14 & 7 & 10 & 14 & 3 & 45 & 7 & 100 & 204 \\
\hline Least expensive & 17 & 15 & 17 & 8 & -- & 24 & 19 & 100 & 202 \\
\hline $\begin{array}{l}\text { Will help the most in meeting growing demands for } \\
\text { energy }\end{array}$ & 7 & 3 & 8 & 22 & 1 & 41 & 18 & 100 & 202 \\
\hline Stimulates economic development the most & 5 & 5 & 8 & 12 & 11 & 24 & 35 & 100 & 203 \\
\hline Diversifies and extends our energy mix the most & 1.5 & 4 & 5 & 11 & 0.5 & 52 & 26 & 100 & 200 \\
\hline Improves the quality of our air the most & -- & 8 & 3 & 6 & -- & 80 & 3 & 100 & 203 \\
\hline Adds the most new high technology jobs & -- & 4 & 2 & 30 & 1 & 40 & 22 & $99 *$ & 201 \\
\hline $\begin{array}{l}\text { Use of this source will increase the most in the } 21 \text { st } \\
\text { century }\end{array}$ & 0.5 & 2 & 7 & 15 & 0.5 & 60 & 15 & 100 & 204 \\
\hline Best for the economy & 4 & 4 & 7 & 12 & 7 & 32 & 33 & $99 *$ & 204 \\
\hline Most positive for you & 1 & 7 & 11 & 7 & 1 & 51 & 22 & 100 & 204 \\
\hline
\end{tabular}


Table A-2. Incremental Monthly Amount Respondents Are Willing to Pay in Electricity Rate Increases to Develop Renewable Forms of Energy

\begin{tabular}{|l|c|}
\hline \multicolumn{2}{|l|}{ If everyone were to pay a slight increase in electricity rates to develop renewable sources of electricity, } \\
what is the most you would be willing to pay? & $\%$ \\
\hline Response categories & 19 \\
\hline Not willing to pay more & 9 \\
\hline $1 / 2 \%$ more (about \$0.23 per month on a typical residential bill) & 11 \\
\hline $1 \%$ more (about \$0.45 per month) & 15 \\
\hline $2 \%$ more (about \$0.90 per month) & 25 \\
\hline $5 \%$ more (about \$2.25 per month) & 19 \\
\hline $10 \%$ more (about $\$ 4.50$ per month) & 2 \\
\hline Other & 100 \\
\hline Total & 202 \\
\hline Base $\mathrm{n}$ & 2 \\
\hline
\end{tabular}


Table A-3. Incremental Monthly Amount Respondents Are Willing to Voluntarily Pay in a Green-Pricing Program

\begin{tabular}{|l|c|}
\hline \multicolumn{2}{|l|}{$\begin{array}{l}\text { At this time, how much more would you choose to pay on your electric bill each } \\
\text { month to ensure that some or all of your electricity comes from renewable sources? }\end{array}$} \\
\hline Response categories & $\%$ \\
\hline Not willing to pay more & 24 \\
\hline \$1 more per month & 14 \\
\hline \$2 more per month & 9 \\
\hline \$3 more per month & 6 \\
\hline \$4 more per month & 2 \\
\hline \$5 more per month & 20 \\
\hline \$6 more per month & 1 \\
\hline \$7 more per month & 18 \\
\hline \$10 more per month & 5 \\
\hline More than \$10 per month & 100 \\
\hline Total & 200 \\
\hline Base n & \\
\hline
\end{tabular}


Table A-4. Reasons for Attitude toward Restructuring (Open-ended question)

\begin{tabular}{|c|c|c|c|c|}
\hline Reasons mentioned & $\%$ & $\begin{array}{c}\text { First } \\
\text { mention } \\
\text { (n) }\end{array}$ & $\begin{array}{l}\text { Second } \\
\text { and third } \\
\text { mention } \\
\text { (n) }\end{array}$ & $\begin{array}{c}\text { Total } \\
\text { mention } \\
\text { (n) }\end{array}$ \\
\hline \multicolumn{5}{|l|}{ Favorable } \\
\hline Competition keeps costs and prices down & 25 & $(42)$ & $(3)$ & $(45)$ \\
\hline Competition is the American way & 8 & $(11)$ & (3) & (14) \\
\hline Like option to choose & 5 & (9) & -- & (9) \\
\hline Monopolies are hard to trust & 2 & (4) & -- & (4) \\
\hline Free enterprise worked before government involvement & $*$ & $(1)$ & -- & $(1)$ \\
\hline Deregulate all utility companies & $*$ & -- & (1) & (1) \\
\hline Monopolies tend to stagnate innovation & 1 & ( 1$)$ & $(1)$ & $(2)$ \\
\hline \multicolumn{5}{|l|}{ Unfavorable } \\
\hline Will or might cost customers more for electricity & 12 & $(15)$ & $(7)$ & $(22)$ \\
\hline Phone restructuring has been a mess for consumers & 11 & $(12)$ & $(7)$ & (19) \\
\hline Worry about service/interrupted power & 6 & $(8)$ & $(3)$ & $(11)$ \\
\hline Electric company can do it & 6 & $(8)$ & $(3)$ & $(11)$ \\
\hline Stay with what works & 3 & (6) & -- & (6) \\
\hline Don't want phone calls wanting me to change & 3 & $(1)$ & $(5)$ & (6) \\
\hline Sounds like a nightmare & 3 & (4) & $(2)$ & (6) \\
\hline Prefer regulated monopolies & 3 & $(2)$ & $(3)$ & $(5)$ \\
\hline Costs of restructuring & 2 & ( 3$)$ & $(1)$ & $(4)$ \\
\hline Large customers will benefit most & 2 & $(1)$ & $(2)$ & ( 3$)$ \\
\hline Will discourage technological improvements in power & 1 & $(1)$ & $(1)$ & $(2)$ \\
\hline Will discourage improvements in transmission systems & 1 & $(1)$ & $(1)$ & $(2)$ \\
\hline Policy makers aren't representing broad public interest & 1 & $(2)$ & -- & $(2)$ \\
\hline \multicolumn{5}{|l|}{ Unsure } \\
\hline Need to know more & 2 & (4) & -- & (4) \\
\hline Totals & $97 * *$ & (136) & (43) & (179) \\
\hline $\begin{array}{l}* \text { Less than } 0.5 \% \text {. } \\
* * \text { Percentages do not add to } 100 \text { because of rounding. }\end{array}$ & & & & \\
\hline
\end{tabular}


Table A-5. Trust in the Utility Company

\begin{tabular}{|c|c|c|c|c|c|}
\hline Statement (1-8 scale) & $\begin{array}{c}\text { Agree or } \\
\text { strongly agree } \\
(6-8) \\
\%\end{array}$ & $\begin{array}{c}\text { Neutral, unsure } \\
(4-5) \\
\%\end{array}$ & $\begin{array}{c}\text { Disagree or } \\
\text { strongly } \\
\text { disagree } \\
(1-3) \\
\%\end{array}$ & Totals & Base $n$ \\
\hline $\begin{array}{l}\text { In general, I am very satisfied with the service I receive } \\
\text { from my utility company }\end{array}$ & 74 & 19 & 7 & 100 & 201 \\
\hline $\begin{array}{l}\text { I believe that my utility company should focus its efforts on } \\
\text { developing clean coal technologies in order to reduce } \\
\text { emissions }\end{array}$ & 59 & 22 & 19 & 100 & 181 \\
\hline $\begin{array}{l}\text { I trust that my utility company makes good decisions on the } \\
\text { selection and development of new power sources }\end{array}$ & 44 & 33 & 23 & 100 & 202 \\
\hline $\begin{array}{l}\text { All I want from my electric utility is that they provide } \\
\text { reliable power at the lowest rate possible }\end{array}$ & 43 & 32 & 25 & 100 & 203 \\
\hline $\begin{array}{l}\text { It really makes no difference to me how my utility company } \\
\text { generates electricity }\end{array}$ & 24 & 22 & 54 & 100 & 200 \\
\hline
\end{tabular}


Table A-6. Criticisms of the Utility Company

\begin{tabular}{|c|c|c|c|c|c|}
\hline Statement (1-8 scale) & $\begin{array}{c}\text { Agree or } \\
\text { strongly agree } \\
\%\end{array}$ & $\begin{array}{c}\text { Neutral/ } \\
\text { unsure } \\
\%\end{array}$ & $\begin{array}{c}\text { Disagree or } \\
\text { strongly } \\
\text { disagree } \\
\%\end{array}$ & Totals & Base $n$ \\
\hline $\begin{array}{l}\text { I believe that my utility company will be forced to use } \\
\text { renewable sources of energy — they will have no choice }\end{array}$ & 57 & 26 & 17 & 100 & 175 \\
\hline $\begin{array}{l}\text { Utility customers don't have enough choice in their electric } \\
\text { services today }\end{array}$ & 53 & 26 & 21 & 100 & 197 \\
\hline $\begin{array}{l}\text { I believe that my utility company is only driven by bottom- } \\
\text { line profitability }\end{array}$ & 46 & 26 & 28 & 100 & 188 \\
\hline $\begin{array}{l}\text { I believe that my utility company is not environmentally } \\
\text { concerned }\end{array}$ & 25 & 26 & 49 & 100 & 171 \\
\hline $\begin{array}{l}\text { I doubt that my utility company has any real commitment to } \\
\text { renewable energy }\end{array}$ & 25 & 34 & 41 & 100 & 168 \\
\hline $\begin{array}{l}\text { I am skeptical about the accuracy of my utility company's } \\
\text { billing system }\end{array}$ & 24 & 29 & 47 & 100 & 191 \\
\hline
\end{tabular}




\section{Table A-7. Position toward Electric Utilities Adding Renewables to Their Fuel Mix}

Many electric utilities in Colorado are considering the addition of renewables as one of the sources from which electricity will be generated. Even though the cost is higher right now, adding these

resources might make sense for long-term environmental, economic, and resource planning reasons.

How do you feel about this? How favorable are you to adding renewable power sources?

\begin{tabular}{|l|c|}
\hline Response (1-10 Scale) & $\%$ \\
\hline Favorable (7-10) & 70 \\
\hline Neutral/mixed (5-6) & 15 \\
\hline Unfavorable (1-4) & 9 \\
\hline Don't know & 6 \\
\hline Total & 100 \\
\hline Base n & 199 \\
\hline
\end{tabular}

\begin{tabular}{|c|c|c|c|c|c|}
\hline $\begin{array}{l}\text { Reason for position ("Please check } \\
\text { the three most important reasons") }\end{array}$ & $\begin{array}{l}\text { Reason } 1 \\
\text { (n) }\end{array}$ & $\begin{array}{l}\text { Reason } 2 \\
\text { (n) }\end{array}$ & $\begin{array}{l}\text { Reason } 3 \\
\text { (n) }\end{array}$ & $\begin{array}{l}\text { Total } \\
\text { (n) }\end{array}$ & $\%$ \\
\hline \multicolumn{6}{|l|}{ Unfavorable } \\
\hline Would cost too much & (43) & -- & -- & $(43)$ & 8 \\
\hline We have plenty of power now & (3) & (1) & -- & (4) & -- \\
\hline Could be bad for utility companies & (3) & (3) & (1) & (7) & 1 \\
\hline It would adversely affect the economy & -- & (6) & (2) & $(8)$ & 1 \\
\hline Seems like we don't need to do this & (1) & (5) & -- & (6) & 1 \\
\hline
\end{tabular}




\begin{tabular}{|c|c|c|c|c|c|}
\hline $\begin{array}{l}\text { Reason for position ("Please check } \\
\text { the three most important reasons") }\end{array}$ & $\begin{array}{c}\text { Reason } 1 \\
(\mathbf{n})\end{array}$ & $\begin{array}{l}\text { Reason } 2 \\
\text { (n) }\end{array}$ & $\begin{array}{l}\text { Reason } 3 \\
\text { (n) }\end{array}$ & $\begin{array}{c}\text { Total } \\
\text { (n) }\end{array}$ & $\%$ \\
\hline Wouldn't necessarily help the environment & (2) & $(6)$ & (6) & (14) & 3 \\
\hline $\begin{array}{l}\text { We have plentiful amounts of } \\
\text { conventional resources in this area }\end{array}$ & (3) & (3) & (3) & (9) & 2 \\
\hline $\begin{array}{l}\text { Don't believe conventional fuels } \\
\text { adversely affect the environment }\end{array}$ & -- & (2) & (7) & (9) & 2 \\
\hline \multicolumn{6}{|l|}{ Favorable } \\
\hline Good for the environment & (97) & (13) & -- & $(110)$ & 20 \\
\hline Helps to conserve natural resources & (29) & (66) & $(8)$ & $(103)$ & 19 \\
\hline Benefits future generations & $(6)$ & (36) & $(38)$ & $(80)$ & 14 \\
\hline $\begin{array}{l}\text { Could be good for the economy } \\
\text { long-term }\end{array}$ & -- & (20) & (9) & (29) & 5 \\
\hline $\begin{array}{l}\text { We need many options to produce } \\
\text { electricity }\end{array}$ & (3) & (16) & $(16)$ & $(35)$ & 6 \\
\hline Could be profitable for utilities & -- & (2) & (3) & $(5)$ & -- \\
\hline $\begin{array}{l}\text { Will need these alternatives for future } \\
\text { energy needs }\end{array}$ & (3) & (6) & (76) & (85) & 15 \\
\hline Seems like the right thing to do & -- & (1) & $(10)$ & (11) & 2 \\
\hline Base $n$ & $(193)$ & $(186)$ & (179) & $(558)$ & $99 *$ \\
\hline
\end{tabular}


Table A-8. Attitudes toward Utility Involvement in Renewables

\begin{tabular}{|c|c|c|c|c|c|}
\hline Statement (1-8 scale) & $\begin{array}{c}\text { Agree or } \\
\text { strongly agree } \\
(6-8) \\
\%\end{array}$ & $\begin{array}{c}\text { Neutral, unsure } \\
(4-5) \\
\%\end{array}$ & $\begin{array}{c}\text { Disagree or } \\
\text { strongly } \\
\text { disagree } \\
(1-3) \\
\%\end{array}$ & Totals & Base $\mathbf{n}$ \\
\hline $\begin{array}{l}\text { I want my utility company to look for new technologies and } \\
\text { sources for generating electricity }\end{array}$ & 77 & 16 & 7 & 100 & 201 \\
\hline $\begin{array}{l}\text { I believe that my utility company should take some of the } \\
\text { risk in developing renewable energy sources }\end{array}$ & 76 & 16 & 8 & 100 & 200 \\
\hline $\begin{array}{l}\text { I am favorable toward my utility's involvement with } \\
\text { developing renewable sources for generating electricity }\end{array}$ & 67 & 25 & 8 & 100 & 182 \\
\hline $\begin{array}{l}\text { I understand that my utility company needs to make profit a } \\
\text { priority when developing alternative energy sources }\end{array}$ & 62 & 21 & 17 & 100 & 198 \\
\hline $\begin{array}{l}\text { My utility company is responsible for developing } \\
\text { renewable energy sources }\end{array}$ & 44 & 37 & 19 & 100 & 152 \\
\hline $\begin{array}{l}\text { I would like to partner with my utility company (be a team } \\
\text { player) in being involved with renewable energy }\end{array}$ & 42 & 37 & 21 & 100 & 190 \\
\hline
\end{tabular}




\section{Appendix B. The "Optional" Questionnaire}




\section{OPTIONAL SECTION ON ENERGY, ENVIRONMENT, AND UTILITY RESTRUCTURING}

\section{If you have time and are particularly interested, we would very much appreciate your answering these additional questions.}

Thank you very much for completing the main questionnaire on grid-tied PV for homes. If you would like an additional opportunity to respond, we would appreciate receiving your views on this questionnaire. These questions deal with broad ideas on energy, the environment, and utility restructuring.

If you have time, please take a few minutes to complete these last few questions. Again, thank you for sharing your views on these topics.

\section{LOTTERY!}

If you choose to complete and return this optional section, we will include your business reply envelope in a $\$ 100$ drawing as a way of thanking you for your additional input.

When you have completed this section, please write the word "Lottery" on the blank envelope before you seal it in the postage-paid business reply envelope, and drop it in the mail. 
Currently, Coloradans are not able to choose their electric service provider. In any community, only one power company provides electricity. Policy makers are considering opening the generation of electric power to competition, allowing customers to choose the power generating company they want to use. The process would be similar to the way consumers can now choose among long-distance providers. However, the company that owns and operates the utility grid (electric lines, towers, and substations) would remain a regulated monopoly. How do you feel about this idea of "restructuring" electricity power production and giving customers a choice? How favorable are you to the idea of electric utility restructuring? [Please circle one response.]

$\begin{array}{ccccccccccccc}\begin{array}{c}\text { Very } \\ \text { unfavorable }\end{array} & 1 & 2 & 3 & 4 & 5 & 6 & 7 & 8 & 9 & 10 & \begin{array}{c}\text { Very } \\ \text { favorable }\end{array} & \begin{array}{c}\text { Don't know } \\ \square\end{array}\end{array}$

Why do you feel this way?

If it came to pass that customers could choose their electricity provider, on a scale of 1 to 10 , how important would each of the following factors be in your choice? [For each factor, please circle one response.]

Not at all

important $\begin{array}{cc}\text { Very } & \text { Don't } \\ \text { important } & \text { know }\end{array}$

$\begin{array}{llllllllll}1 & 2 & 3 & 4 & 5 & 6 & 7 & 8 & 9 & 10\end{array}$

1. Price of the electricity offered by the provider ............

2. Environmental effects of producing the electricity ........... $\ldots \begin{array}{lllllllllll}1 & 2 & 3 & 4 & 5 & 6 & 7 & 8 & 9 & 10\end{array}$

3. Quality of customer service ....................

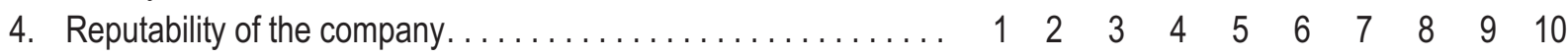

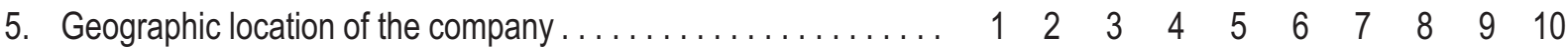

\section{NEXT ARE SOME QUESTIONS ABOUT ELECTRICITY SOURCES AND RENEWABLE ENERGY.}

Which source of electricity do you think of most when you read each of the following phrases? [For each phrase, please circle only one energy source.]

Electricity sources

\begin{tabular}{cccccc}
\hline Coal & $\begin{array}{c}\text { Hydro- } \\
\text { power }\end{array}$ & $\begin{array}{c}\text { Natural } \\
\text { gas }\end{array}$ & Nuclear & Oil $\begin{array}{c}\text { Solar } \\
\text { and wind }\end{array}$ & $\begin{array}{c}\text { Don't } \\
\text { know }\end{array}$ \\
\hline
\end{tabular}

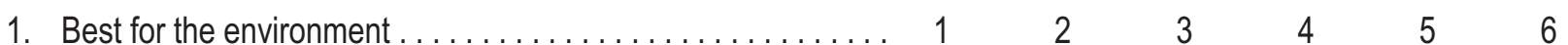

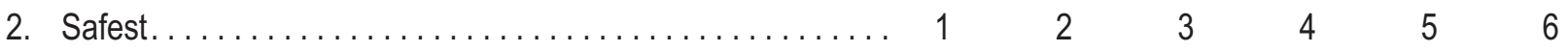

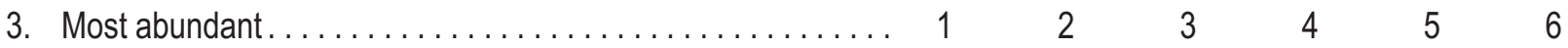

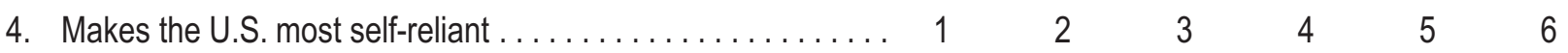

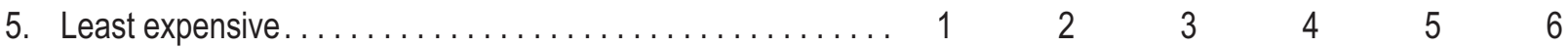

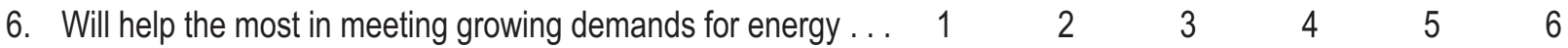

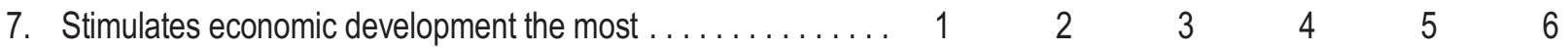

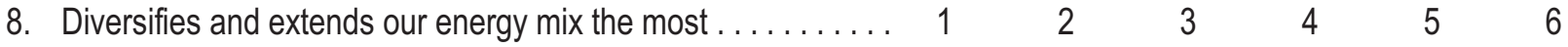

9. Improves the quality of our air the most $\ldots \ldots \ldots \ldots \ldots \ldots$. $\ldots$.

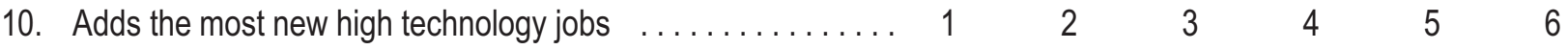

11. Use of this energy source will increase the most

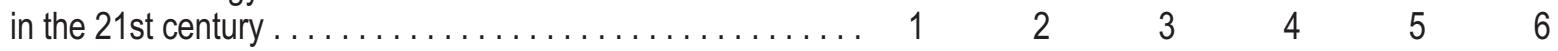

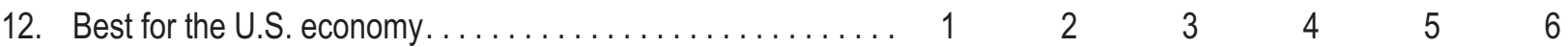

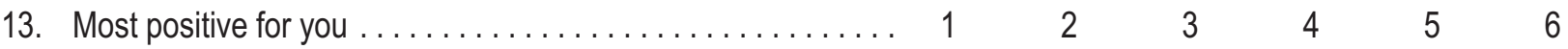

Listed below are a number of energy sources often thought of as renewable. Of these choices, which three do you think would be best to use for meeting energy needs in Colorado? [Please rank your top three choices, with 1 as your first choice, 2 as your second choice, and 3 as your third choice.] 
1. Biomass power (burning forest or agricultural waste, or energy crops)

2. Burning municipal solid waste

3. Geothermal (heat from within the Earth's crust)

4. Ground-source heat pumps

5. Small-scale hydropower

6. Large-scale hydropower

7. Landfill gas

8. Passive solar houses

9. Solar cells (photovoltaics/PV) for electricity

10. Active solar (solar domestic hot water systems)

11. Wind power

12. Other [Please specify]

Many electric utilities in Colorado are considering the addition of renewables as one of the sources from which electricity will be generated. Even though the cost is higher right now, adding these resources might make sense for long-term environmental, economic, and resource planning reasons. How do you feel about this? How favorable are you to adding renewable power sources? [Please circle one response.]

$\begin{array}{ccccccccccccc}\begin{array}{c}\text { Very } \\ \text { unfavorable }\end{array} & 1 & 2 & 3 & 4 & 5 & 6 & 7 & 8 & 9 & 10 & \begin{array}{c}\text { Very } \\ \text { favorable }\end{array} & \begin{array}{c}\text { Don't know } \\ \square\end{array}\end{array}$

Why do you feel that way? [Please check the three most important reasons.]

Unfavorable

Favorable

Electricity from renewables costs more than electricity from conventional energy sources. However, some argue that using renewables benefits everyone. If utilities were to develop renewables as part of their power mix, how should the cost be paid for? [Please check one response.]

1. Everyone's rates should be increased slightly

2. Only those who choose renewable sources should pay

3. Both (a slight rate increase for everyone, plus those who specifically choose renewable sources should be charged more)

4. The federal government should subsidize power generation from renewables just as it subsidizes power generation from other fuels

5. Should not develop renewables as part of the utility power mix

6. Other [Please specify]

If everyone were to pay a slight increase in electricity rates to develop renewable sources of electricity, what is the most you would be willing to pay? [Please check one response.]

1. $1 / 2 \%$ more (about $23 \notin$ per month on a typical residential bill)

2. $1 \%$ more (about $45 \phi$ per month)

3. $2 \%$ more (about $90 \propto$ per month)

4. $5 \%$ more (about $\$ 2.25$ per month)

5. $10 \%$ more (about $\$ 4.50$ per month)

6. 0 (not willing to pay more)

7. Other [Please specify]

\section{NOW, TWO QUESTIONS ON THE VOLUNTARY ACTIONS OF ELECTRICITY CUSTOMERS...}

Assume that for the immediate future, the use of renewable electricity sources will depend on the voluntary actions of electricity customers. If paying for renewable electricity were offered on a voluntary basis, how likely would you 
be to pay more money on a monthly basis to get some or all of your electricity from renewables? Would you say...? [Please circle one response.]

$\begin{array}{llllllllllllc}\begin{array}{l}\text { Very } \\ \text { unlikely }\end{array} & 1 & 2 & 3 & 4 & 5 & 6 & 7 & 8 & 9 & 10 & \begin{array}{c}\text { Very } \\ \text { likely }\end{array} & \text { Don't know } \\ \square\end{array}$

At this time, how much more would you choose to pay on your electric bill each month to ensure that some or all of your electricity comes from renewable sources? [Please check one response.]

1. $\$ 1$ more per month

$\square$ 2. $\$ 2$ more

3. $\$ 3$ more

4. $\$ 4$ more

5. $\$ 5$ more

6. $\$ 6$ more

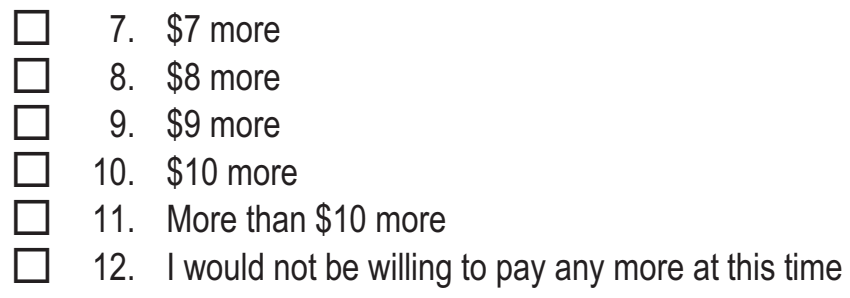

NOW, TWO QUESTIONS ON ENVIRONMENTAL PROBLEMS...

On a 1 to 10 scale, how important do you think each of the following environmental problems is in today's world?

\begin{tabular}{|c|c|c|c|c|c|c|c|c|c|c|c|}
\hline & $\begin{array}{l}\text { Not at } \\
\text { import }\end{array}$ & & & & & & & & & $\begin{array}{l}\text { Very } \\
\text { portant }\end{array}$ & $\begin{array}{l}\text { Don't } \\
\text { know }\end{array}$ \\
\hline 1. Acid rain. & 1 & 2 & 3 & 4 & 5 & 6 & 7 & 8 & 9 & 10 & $\square$ \\
\hline 2. Air pollution.... & 1 & 2 & 3 & 4 & 5 & 6 & 7 & 8 & 9 & 10 & $\square$ \\
\hline 3. Climate change/global warming & 1 & 2 & 3 & 4 & 5 & 6 & 7 & 8 & 9 & 10 & $\square$ \\
\hline 4. Hazardous/toxic waste $\ldots \ldots \ldots \ldots \ldots$ & 1 & 2 & 3 & 4 & 5 & 6 & 7 & 8 & 9 & 10 & $\square$ \\
\hline 5. Loss of habitat or species (extinction).... & 1 & 2 & 3 & 4 & 5 & 6 & 7 & 8 & 9 & 10 & $\square$ \\
\hline 6. Mining or strip-mining $\ldots \ldots \ldots \ldots \ldots$ & 1 & 2 & 3 & 4 & 5 & 6 & 7 & 8 & 9 & 10 & $\square$ \\
\hline 7. Oil spills ................ & 1 & 2 & 3 & 4 & 5 & 6 & 7 & 8 & 9 & 10 & $\square$ \\
\hline 8. Radioactive waste . & 1 & 2 & 3 & 4 & 5 & 6 & 7 & 8 & 9 & 10 & $\square$ \\
\hline 9. Using up natural resources ......... & 1 & 2 & 3 & 4 & 5 & 6 & 7 & 8 & 9 & 10 & $\square$ \\
\hline 10. Water pollution ............. & 1 & 2 & 3 & 4 & 5 & 6 & 7 & 8 & 9 & 10 & $\square$ \\
\hline 11. Other [Please specify] & -1 & 2 & 3 & 4 & 5 & 6 & 7 & 8 & 9 & 10 & $\square$ \\
\hline
\end{tabular}

On a 1 to 10 scale, to what extent do you feel our environmental problems are related to energy production and use? [Please circle one response.]

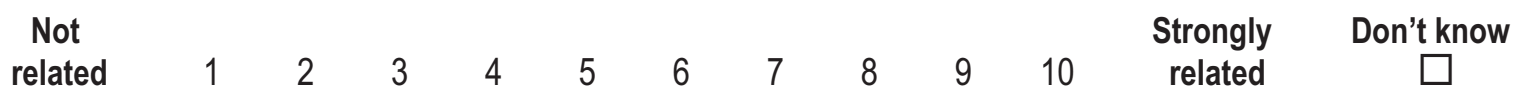

Listed below are several energy sources that are used to generate electricity. As you read each one, please circle any number from 1 to 10, where 1 means "no environmental threat," and 10 means "a large environmental threat" to show how much of an environmental threat you think that energy source is when used to generate electricity. [Please circle one response.]

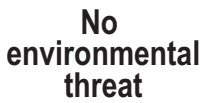

1. Coal

2. Hydropower .................. 12

3. Natural gas................... 12

4. Nuclear. . . . . . . . . . . . . . . . . . . 12

5. Oil...................... 12

6. Solar..................... 1

7. Solid waste incineration ........... 1

8. Wind $\ldots \ldots \ldots \ldots \ldots \ldots \ldots \ldots \ldots, 12$

$\begin{array}{llllllll}3 & 4 & 5 & 6 & 7 & 8 & 9 & 10 \\ 3 & 4 & 5 & 6 & 7 & 8 & 9 & 10 \\ 3 & 4 & 5 & 6 & 7 & 8 & 9 & 10 \\ 3 & 4 & 5 & 6 & 7 & 8 & 9 & 10 \\ 3 & 4 & 5 & 6 & 7 & 8 & 9 & 10 \\ 3 & 4 & 5 & 6 & 7 & 8 & 9 & 10 \\ 3 & 4 & 5 & 6 & 7 & 8 & 9 & 10 \\ 3 & 4 & 5 & 6 & 7 & 8 & 9 & 10\end{array}$

$\begin{array}{cc}\begin{array}{c}\text { Large } \\ \text { environmental } \\ \text { threat }\end{array} & \text { Don't } \\ \text { know }\end{array}$


FINALLY, SOME STATEMENTS ABOUT YOUR UTILITY COMPANY...

Please give us your opinion on the following statements concerning your utility company and renewable electricity.

Would you say you agree or disagree with the following statements? [For each statement, please circle one response.] Strongly disagree

Strongly Don't agree know

1. It really makes no difference to me how my utility company generates electricity

$\begin{array}{llllllll}1 & 2 & 3 & 4 & 5 & 6 & 7 & 8\end{array}$

2. I trust that my utility company makes good decisions on the selection

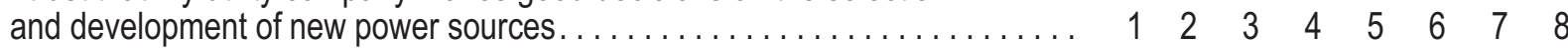

3. All I want from my electric utility is that they provide reliable power at the lowest rate possible.

4. I want my utility company to look for new technologies and sources for generating electricity

5. Utility customers don't have enough choice in their electric service today . . . $\quad \begin{array}{lllllllllll} & 2 & 3 & 4 & 5 & 6 & 7 & 8\end{array}$

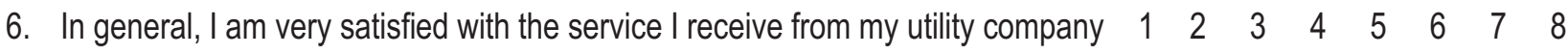

7. My utility company is responsible for developing renewable energy sources ..

8. I believe that my utility company should focus its efforts on developing clean coal technologies in order to reduce emissions................

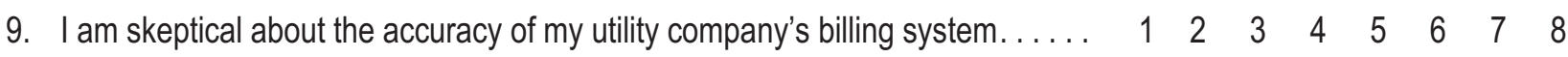

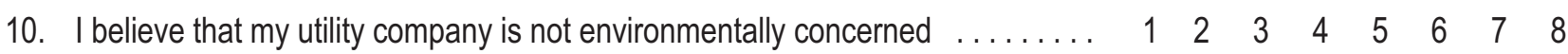

11. I doubt that my utility company has any real commitment to renewable energy $\quad \begin{array}{lllllllll}2 & 2 & 3 & 4 & 5 & 6 & 7 & 8\end{array}$

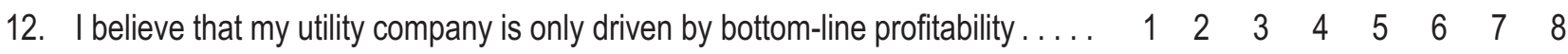

13. I am favorable toward my utility's involvement with developing renewable

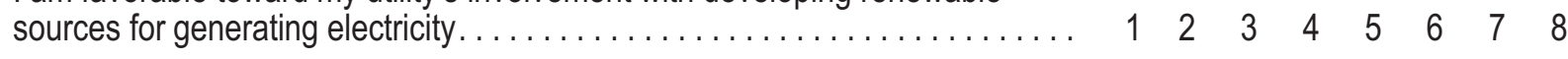

14. I understand that my utility company needs to make profit a priority when developing alternative energy sources

15. I believe that my utility company will be forced to use renewable sources

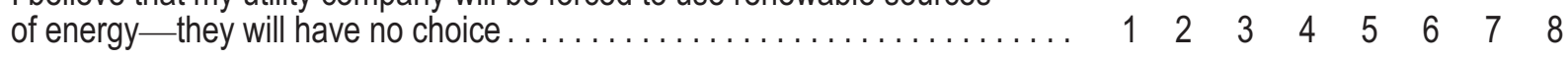

16. I would like to partner with my utility company (be a team player) in being involved with renewable energy $\ldots \ldots \ldots \ldots \ldots \ldots \ldots \ldots \ldots \ldots \ldots \ldots$

17. I believe that my utility company should take some of the risk in developing renewable energy sources

$\begin{array}{llllllll}1 & 2 & 3 & 4 & 5 & 6 & 7 & 8\end{array}$

\section{THANK YOU FOR COMPLETING THIS OPTIONAL SECTION!}




\section{REPORT DOCUMENTATION PAGE}

Form Approved

OMB NO. 0704-0188

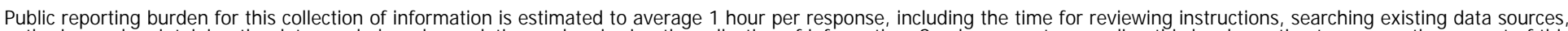

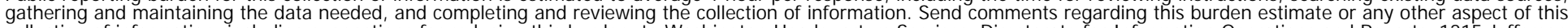

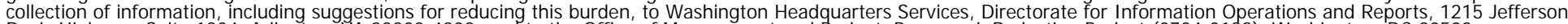

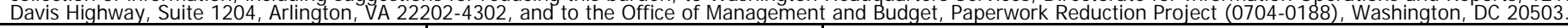

\begin{tabular}{|l|l|l|}
\hline 1. AGENCY USE ONLY (Leave blank) & $\begin{array}{l}\text { 2. REPORT DATE } \\
\text { June } 1999\end{array}$ & $\begin{array}{l}\text { 3. REPORT TYPE AND DATES COVERED } \\
\text { Technical Report }\end{array}$ \\
\hline 4. TITLE AND SUBTITLE &
\end{tabular}

Colorado Homeowner Preferences on Energy and Environmental Policy

5. FUNDING NUMBERS

6. AUTHOR(S)

AS135444

Barbara C. Farhar; Timothy C.Coburn

7. PERFORMING ORGANIZATION NAME(S) AND ADDRESS(ES)

National Renewable Energy Laboratory

1617 Cole Boulevard

Golden, CO 80401-3393

8. PERFORMING ORGANIZATION

REPORT NUMBER

TP 550-25285

9. SPONSORING/MONITORING AGENCY NAME(S) AND ADDRESS(ES)

National Renewable Energy Laboratory

1617 Cole Blvd.

10. SPONSORING/MONITORING AGENCY REPORT NUMBER

Golden, CO 80401-3393

TP-550-25285

11. SUPPLEMENTARY NOTES

NREL Technical Monitor:

12a. DISTRIBUTION/AVAILABI LITY STATEMENT

National Technical Information Service

12b. DISTRIBUTION CODE

U.S. Department of Commerce

5285 Port Royal Road

Springfield, VA 22161

13. ABSTRACT (Maximum 200 words)

This survey inquiring into Colorado homeowners' preferences on energy and environmental policy shows that more-affluent, married Colorado single-family homeowners are somewhat favorable to utility restructuring; want to see green power developed; prefer to share the costs broadly by various means; are willing to pay slightly higher electricity rates to develop renewable sources of electricity; and believe that utility customers don't have enough choice in their electric service today.

14. SUBJ ECT TERMS

energy; renewable energy; solar energy; green power; homeowners; public opinion; survey; utility; energy policy; environment; environment policy; utility restructuring

15. NUMBER OF PAGES 33

16. PRICE CODE

17. SECURITY CLASSIFICATION OF REPORT

18. SECURITY CLASSIFICATION OF THIS PAGE
19. SECURITY CLASSIFICATION OF ABSTRACT
20. LIMITATION OF ABSTRACT

L 